\title{
Fragmentation of Negative Ions from Carbohydrates: Part 3. Fragmentation of Hybrid and Complex $N$-Linked Glycans
}

\author{
David J. Harvey \\ Department of Biochemistry, Glycobiology Institute, University of Oxford, Oxford, United Kingdom
}

\begin{abstract}
Hybrid and complex $\mathrm{N}$-linked glycans were ionized by electrospray in the presence of ammonium nitrate to give $\left[\mathrm{M}+\mathrm{NO}_{3}\right]^{-}$and $\left[\mathrm{M}+\left(\mathrm{NO}_{3}\right)_{2}\right]^{2-}$ ions. Low energy collisioninduced decomposition (CID) spectra of both types of ions were almost identical and were dominated by C-type glycosidic and cross-ring fragments, unlike the corresponding spectra of the positive ions that contained mainly B- and Y-type glycosidic fragments. Also, in contrast to fragments in the positive ion spectra, many of these ions appeared to be produced by single pathways following proton abstraction from specific hydroxy groups. Consequently, many ions were diagnostic for specific structural features. Such features included the composition of each of the two antennas, the presence or absence of a bisecting GlcNAc residue, and the location of fucose residues on the core GlcNAc residues and on the antennas. C-ions defined the sequence of the constituent monosaccharide residues. Detailed fragmentation mechanisms are proposed to account for several of the diagnostic ions. (J Am Soc Mass Spectrom 2005, 16, 647-659) @ 2005 American Society for Mass Spectrometry
\end{abstract}

$\mathrm{N}$ -linked glycans, those attached to asparagine in glycoproteins, play a fundamental role in determining the biophysical properties of these compounds [1,2]. Structural determination of these compounds has classically been performed by chemical or enzymatic release followed by exoglycosidase digestion, with products monitored by gel filtration chromatography [3] or, more recently, high-performance liquid chromatography (HPLC) [4-6] or matrix-assisted laser desorption/ionization (MALDI) mass spectrometry [7, 8]. More recently, in response to the introduction of mass spectrometers, such as the tandem quadrupoletime-of-flight instruments and problems with the commercial availability of exoglycosidases, an increasing number of investigators are using wholly mass spectrometric-based approaches for the analysis of these compounds (see for example the recent review by Zaia [9]).

Most of this work has concentrated on the production and fragmentation of positive ions although it has become apparent in recent years [10-16] that negative ion fragmentation produces complementary information and can, in many cases, yield less ambiguous spectra than those provided by positive ion spectra. We have recently investigated methods for producing stable negative ions from $N$-linked glycans and found that nitrate adducts, formed by electrospray from solvents containing small amounts of ammonium nitrate, yield intense negative ions that, on fragmentation, give several characteristic and diagnostic

Published online March 11, 2005

Address reprint requests to Dr. D. J. Harvey, Department of Biochemistry, Glycobiology Institute, University of Oxford, South Parks Road, Oxford OX1 3QU, United Kingdom. E-mail: dh@glycob.ox.ac.uk ions that are not present in the corresponding positive ion spectra [17]. Details of the fragmentation of high-mannose $N$-linked glycans, the early compounds in the biosynthesis of these compounds, were reported in an earlier paper [18] and this paper concentrates on the fragmentation of hybrid and complex glycans.

\section{Materials and Methods}

\section{Materials}

Hybrid and complex glycans were released with hydrazine $[19,20]$ from the well-characterized glycoproteins: porcine thyroglobulin [21,22], chicken ovalbumin [23, 24], bovine fetuin [25], thyroglobulin and $\alpha 1$-acid glycoprotein $[26]^{\circ}$ obtained ${ }^{\circ}$ from $^{\circ}$ Sigma ${ }^{\circ} \mathrm{Chemical}{ }^{\circ} \mathrm{Co} .{ }^{\circ} \mathrm{Ltd}$. (Poole, Dorset, UK). Bi- and tri-antennary complex $\mathrm{N}$-linked glycans were obtained as reference compounds from Oxford GlycoSciences Ltd., (Abingdon, UK) or were derived from the sialylated glycans by desialylation with $10 \%$ acetic acid for $30 \mathrm{~min}$ at $80^{\circ} \mathrm{C}$. Ammonium nitrate was from Aldrich Chemical Co. Ltd (Poole, UK). Methanol was obtained from BDH Ltd. (Poole, UK). Water was distilled before use.

\section{Methylation of the Carboxy Group of Sialic Acids}

In order to stabilize the sialic acids, the carboxy groups of $^{\circ}$ glycans ${ }^{\circ}$ from $^{\circ}{ }^{\circ}$ ovine ${ }^{\circ}$ fetuin, ${ }^{\circ}$ as $^{\circ} a^{\circ}$ representative ${ }^{\circ}$ example, were converted into their methyl esters by exchanging the protons for sodium and reacting the product with methyl iodide as described by Powell and Harvey ${ }^{\circ}[27]$. 

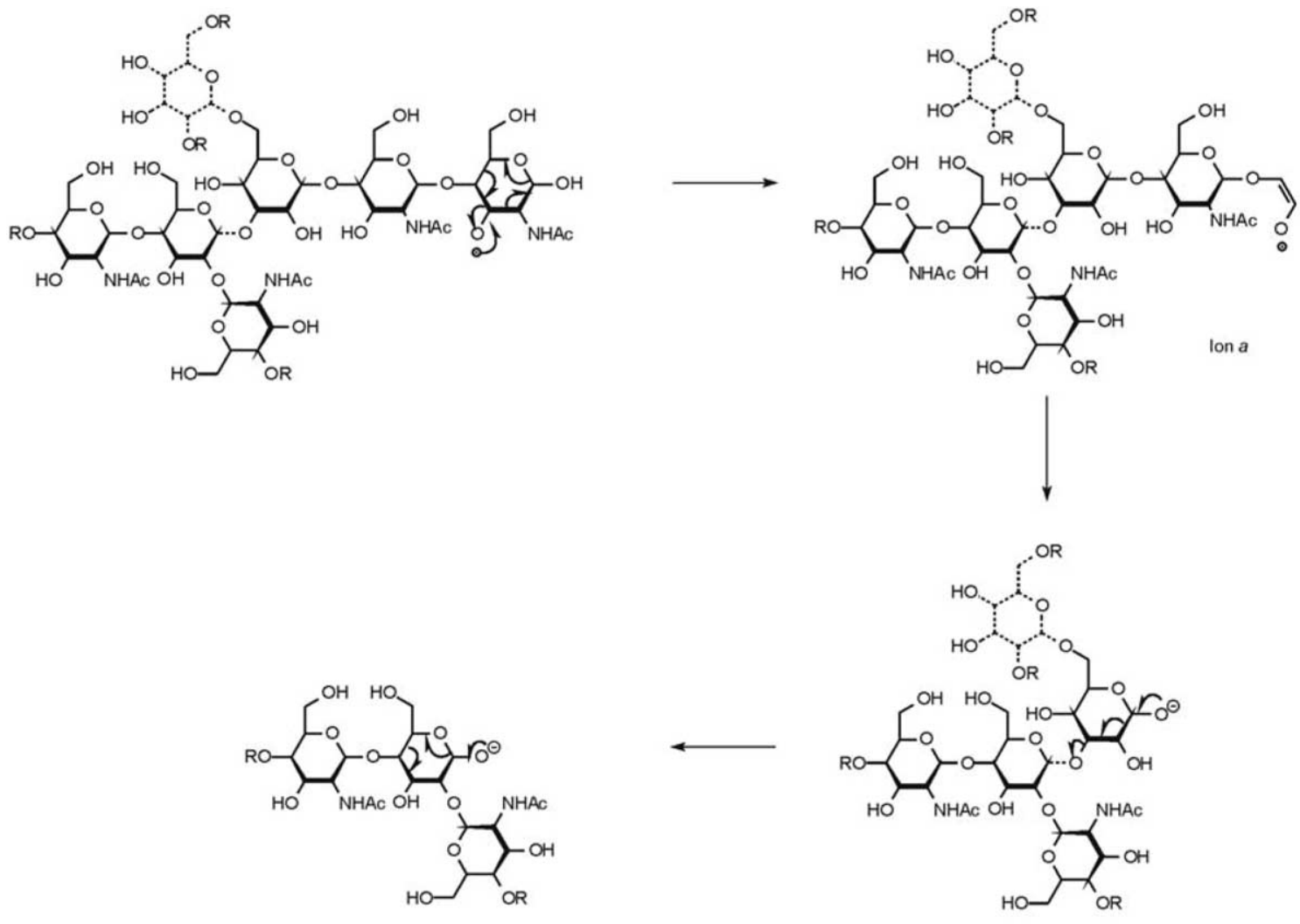

Ion $c$
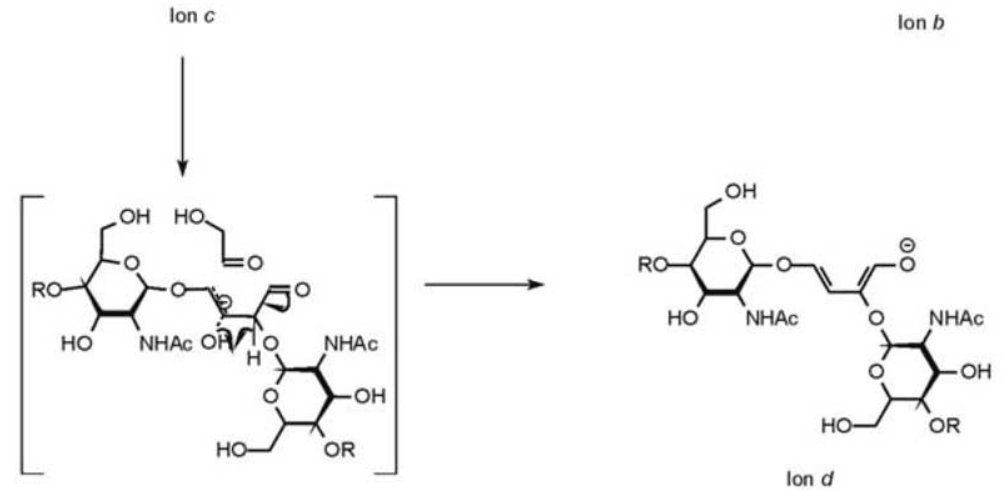

Scheme 1. Proposed mechanism for the formation of the ion E (Ion $d$ ).

\section{Electrospray Mass Spectrometry}

Electrospray ionization mass spectrometry was performed with a Waters-Micromass quadrupole-time-offlight (Q-TOF) Ultima Global instrument (Waters/Mi-

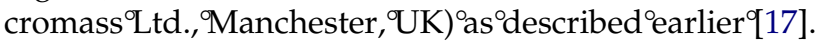

\section{Investigations of the Effect of the RF-1 and}

\section{Collision Cell Voltages}

The carbohydrates, in solutions containing ammonium nitrate, were infused at $5 \mu \mathrm{L} / \mathrm{min}$ at a concentration of about 50 pmol total glycans $/ \mu \mathrm{L}$ and spectra were recorded for $20 \mathrm{~s}$ with an acquisition time of $2 \mathrm{~s}$ (10 scans). For measurements of the effect of the RF-1 potential, this voltage was raised in $10 \mathrm{~V}$ steps from 0 to $250 \mathrm{~V}$ and spectra were recorded at each voltage. For measurements of the effect of collision cell potential, the RF-1 voltage was set at 250 and $80 \mathrm{~V}$ for the singly- and doubly-charged respectively and the collision cell potential was raised in $2 \mathrm{~V}$ steps from the voltage at which the fragments started to appear until most ions had fragmented.

\section{Results and Discussion}

\section{Ion Nomenclature}

Ion nomenclature follows that proposed by Domon and

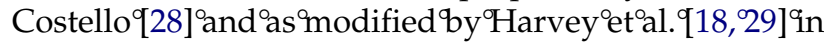
order to accommodate changes in the glycan numbering as the result of differing antenna lengths. The numbering system for fragments retains that for the molecular ion. 


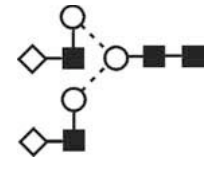

1, Biantennary

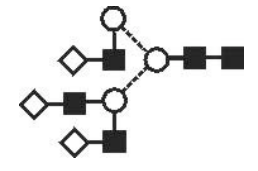

2, triantennary

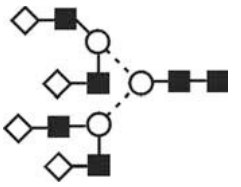

3, Tetra-antennary

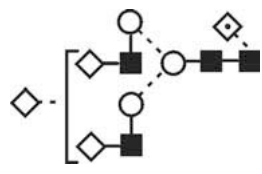

4

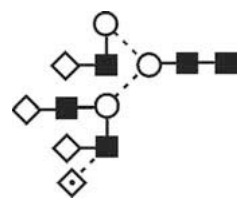

5

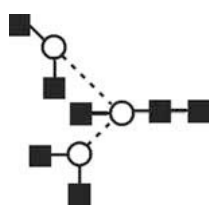

6

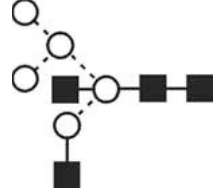

7

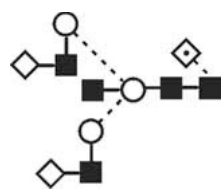

8

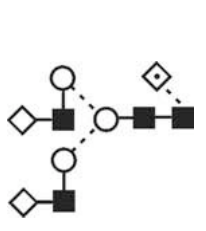

9

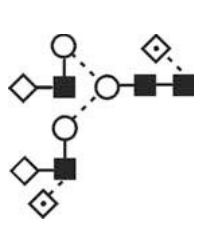

10

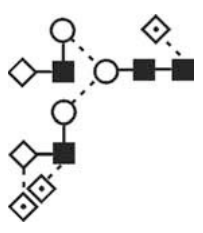

11

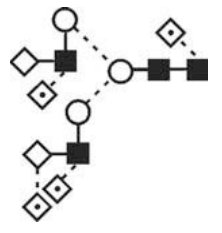

12

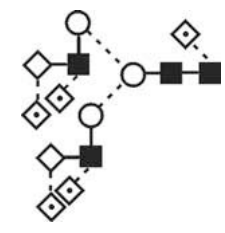

13

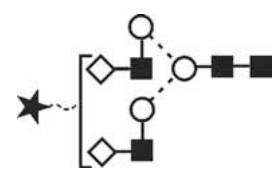

14

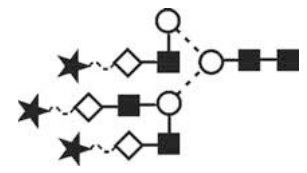

15

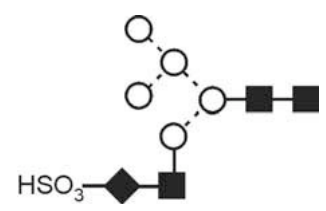

16

Figure 1. Structures of the glycans whose fragmentation is discussed in this paper. Key to symbols for this and subsequent figures: open circle $=$ mannose, filled square $=$ GlcNAc, open diamond $=$ galactose, diamond with a dot in the center $=$ fucose, filled star $=N$-acetylneuraminic (sialic) acid. The linkage position is shown by the angle of the lines linking the sugar residues (vertical line $=2$-link, forward slash $=3$-link, horizontal line $=4$-link, back slash $=6$-link). Full lines $=\beta$-bonds, broken lines $=\alpha$-bonds. A wavy line linking the sialic acid residues indicates the presence of both $\alpha 2 \rightarrow 3$ and $\alpha 2 \rightarrow 6$ linkages.

\section{Ions Produced by Fragmentation of the Chitobiose Core}

Fragmentation of the chitobiose core of the hybrid and complex neutral glycans produced the same ions as noted $^{\circ}$ earlier ${ }^{\circ}[18]^{\circ}$ for $^{\circ}$ fragmentation ${ }^{\circ}$ of ${ }^{\circ}$ the ${ }^{\circ}$ high-mannose glycans. Thus, the most abundant ions were the ${ }^{2,4} \mathrm{~A}_{\mathrm{R}}$ (Ion $a$, Scheme 1) and ${ }^{2,4} \mathrm{~A}_{\mathrm{R}-1}$ ions at $[\mathrm{M}-\mathrm{HR}-$ $161]^{-}$and $[\mathrm{M}-\mathrm{HR}-364]^{-}$(where $\mathrm{R}$ is the attached anion) ${ }^{\circ}$ (Figures $2,{ }^{\circ} 3 \mathrm{~b},{ }^{\circ} 4 \mathrm{a},{ }^{\circ} 5 \mathrm{a}$ ). ${ }^{\circ}$ When ${ }^{\circ}$ fucose ${ }^{\circ}$ was ${ }^{\circ}$ present at the 6-position of the reducing-terminal GlcNAc resi-

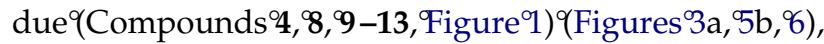
these ions appeared at $[\mathrm{M}-\mathrm{HR}-307]^{-}$and $[\mathrm{M}-\mathrm{HR}$ - 510] ${ }^{-}$as the fucose was lost. For example, in the spectrum of the complex bi-antennary glycan, $(\mathrm{Gal})_{2}(\mathrm{Man})_{3}(\mathrm{GlcNAc})_{4}\left(\mathbf{1}^{\circ}{ }^{\circ}\right.$ Figure $\left.^{\circ} 2 \mathrm{a}\right){ }^{\circ}$, these ${ }^{\circ}$ two ${ }^{\circ}$ ions appeared at $\mathrm{m} / \mathrm{z} 1478.6\left({ }^{2,4} \mathrm{~A}_{\mathrm{R}}\right)$ and $1275.5\left({ }^{2,4} \mathrm{~A}_{\mathrm{R}-1}\right)$, respectively. B-type fragments and the ${ }^{\mathrm{O}, 2} \mathrm{~A}_{R}$ cross-ring fragment observed earlier were also present in all spectra. Mechanisms for the formation of these ions were $^{\circ}$ proposed $^{\circ}$ earlier ${ }^{\circ}[18]$. 


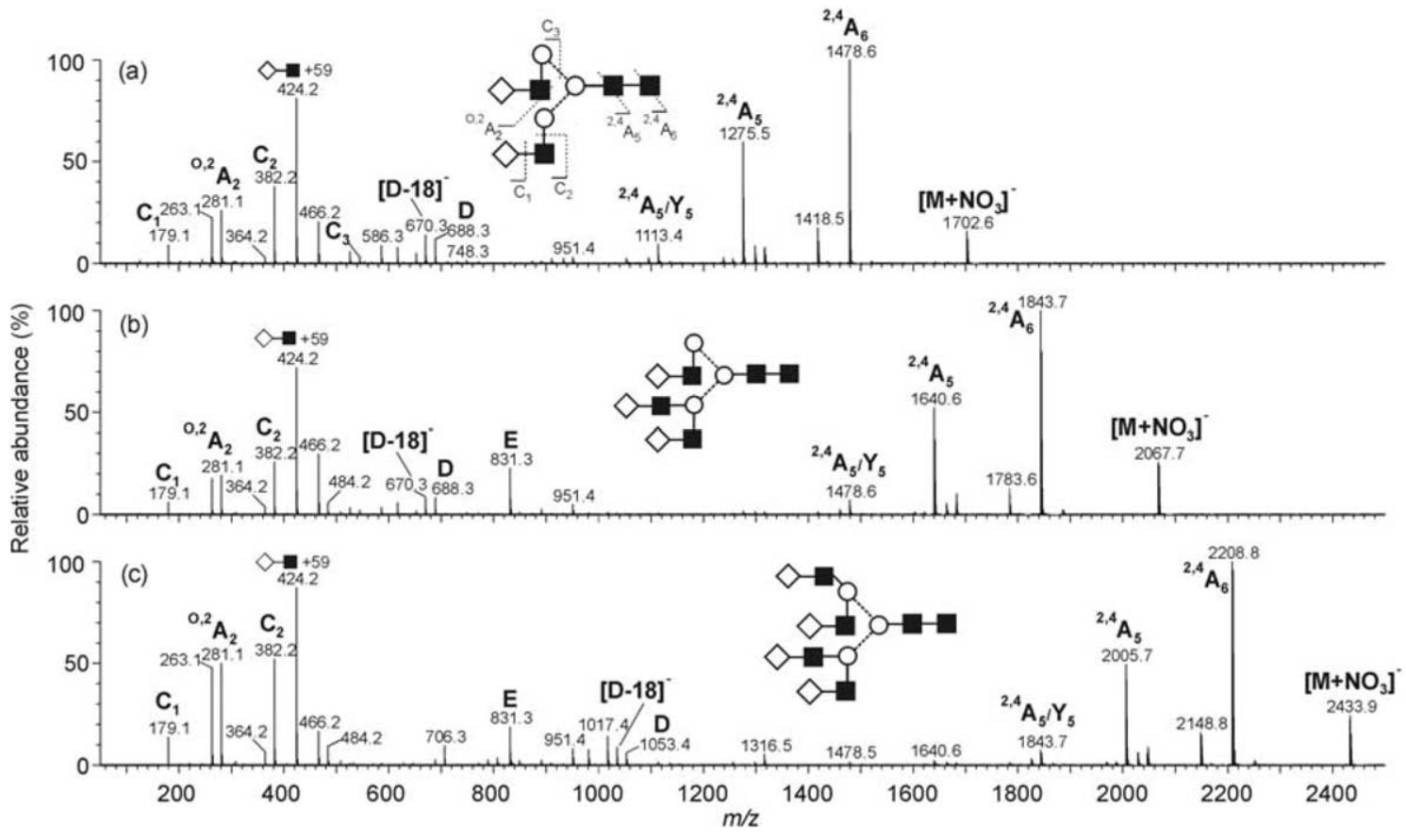

Figure 2. CID spectra of the $\left[\mathrm{M}+\mathrm{NO}_{3}\right]^{-}$ions from the complex (a) bi- (1) (b), tri- (2), and (c) tetra-antennary (3) glycans.

\section{Ions Specific to the 6-Antenna}

The D (Ion e, Scheme 2) and [D - 18] ${ }^{-}$ions reported earlier $[18]^{\circ}$ as $^{\circ}$ being $^{\circ}$ diagnostic $^{\circ}$ for $^{\circ}$ the $^{\circ}$ composition $^{\circ}$ of the 6-antennas were prominent in the spectra of all glycans that did not contain a bisecting GlcNAc residue (see below). Thus, complex glycans containing a 6-antenna having the Gal $\rightarrow$ GlcNAc $\rightarrow$ Man chain (biantennary ${ }^{\circ}\left[\mathbf{1}^{\circ}\right.$ Figure $^{\circ} 2 \mathrm{a}^{\circ}$ and $^{\circ} 3$-branched ${ }^{\circ}$ tri-antennary $\left[2,{ }^{\circ}\right.$ Figure $\left.\left.^{\circ} 2 \mathrm{~b}\right]\right)^{\circ}$ gave $^{\circ} \mathrm{m} / \mathrm{z} 688.3^{\circ}$ and $^{\circ} 670.3^{\circ}$ whereas ${ }^{\circ}$ tetraantennary ${ }^{\circ}\left(3,{ }^{\circ} \text { Figure }^{\circ} 2 \mathrm{c}\right)^{\circ}$ and $^{\circ} 6$-branched ${ }^{\circ}$ tri-antennary glycans gave spectra containing $\mathrm{m} / \mathrm{z} 1053.4$ and 1035.4.

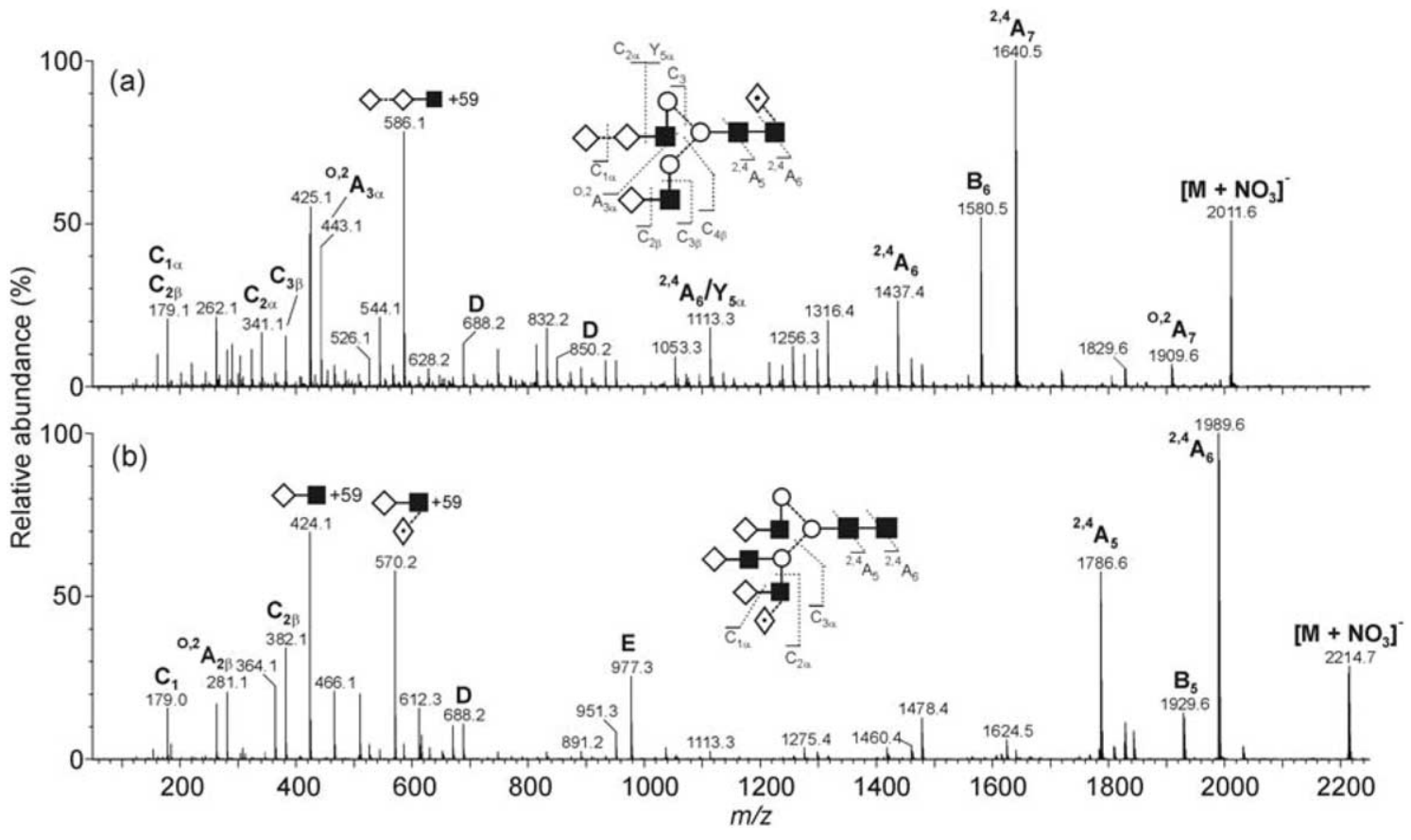

Figure 3. CID spectra of the $\left[\mathrm{M}+\mathrm{NO}_{3}\right]^{-}$ion from (a) the $\alpha$-galactosylated bi-antennary glycan (4) from porcine thyroglobulin and (b) the monofucosylated tri-antennary glycan (5) from human $\alpha 1$-acid glycoprotein. 


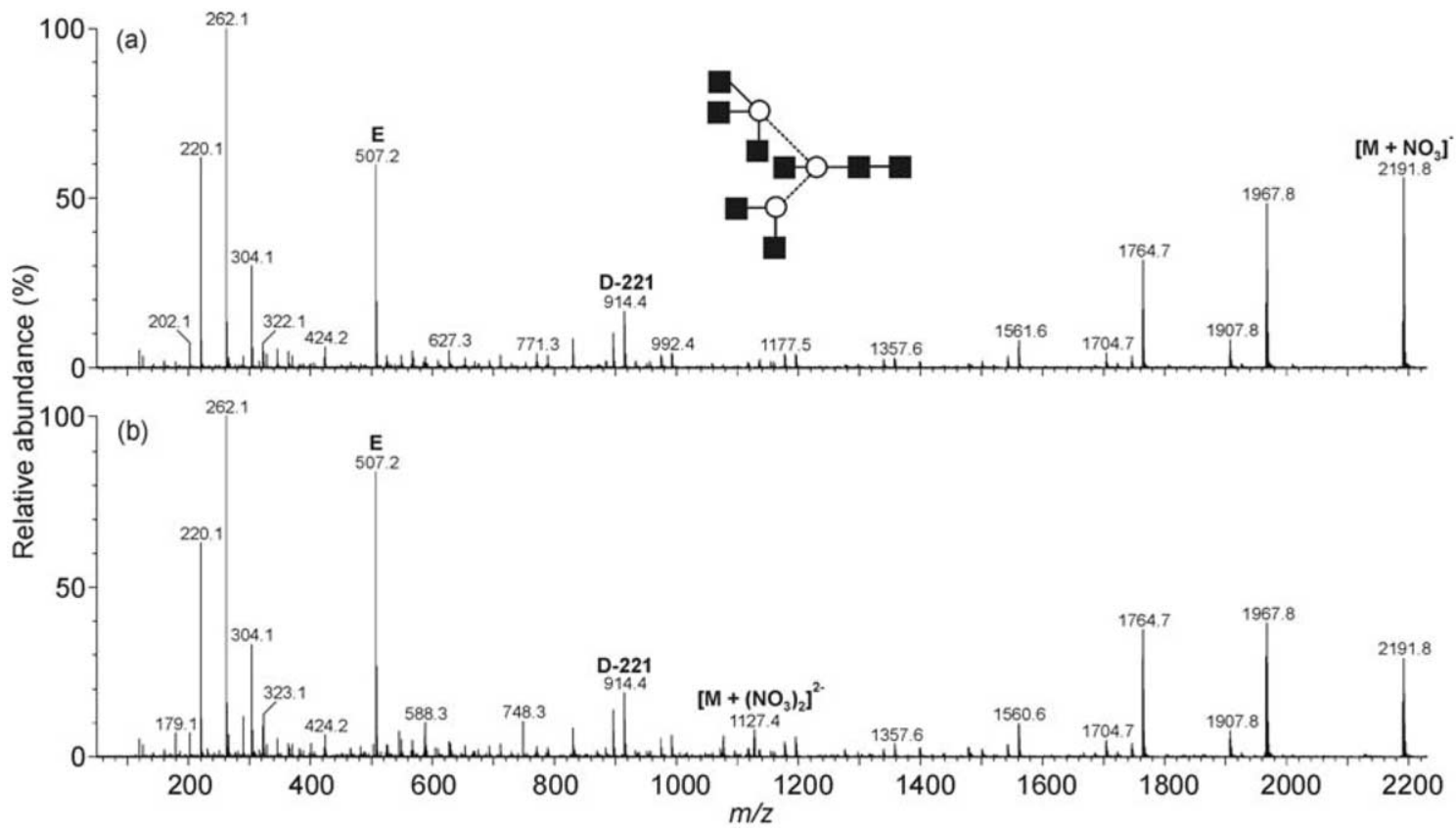

Figure 4. CID spectrum of (a) the $\left[\mathrm{M}+\mathrm{NO}_{3}\right]^{-}$ion and (b) the $\left[\mathrm{M}+\left(\mathrm{NO}_{3}\right)_{2}\right]^{2-}$ ion from the complex penta-antennary glycan (6) from chicken egg-white glycoproteins.

The presence of an $\alpha$-galactose residue on both the 3and 6-antenna of one of the glycans from porcine thyroglobulin (Compound 4) was demonstrated by the presence of the $\mathrm{D}$ and $[\mathrm{D}-18]^{-}$ions at $m / z$ 688.2, 770.2, and $^{\circ}$ at $^{\circ} \mathrm{m} / \mathrm{z} 850.3,{ }^{\circ} 832.3,{ }^{\circ}$ respectively ${ }^{\circ}$ (Figure $\left.{ }^{\circ} 3 \mathrm{a}\right) .{ }^{\circ}$ Previous $^{\circ}$ reports ${ }^{\circ}[21]^{\circ}$ had $^{\circ}$ suggested ${ }^{\circ}$ that ${ }^{\circ}$ only ${ }^{\circ}$ the ${ }^{\circ} 6$-antenna was substituted with an $\alpha$-galactose residue but the complexity of the spectrum clearly shows that it is from

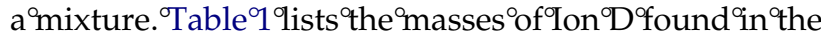
spectra of common $N$-linked glycans. The $\mathrm{D}$ ion appears to be formed by a $\mathrm{C}_{\mathrm{R}-1} / \mathrm{Z}^{\circ}$ cleavage $^{\circ}[18]^{\circ}$ unlike $^{\circ}$ its formation in positive ion spectra where a $\mathrm{B} / \mathrm{Y}$ cleavage appears $^{\circ}$ to $^{\circ}$ be $^{\circ}$ involved $[29] .{ }^{\circ}, 3 \mathrm{~A}_{4}$ cross-ring cleavages (e.g., $\mathrm{m} / \mathrm{z}$ 616.3, ${ }^{\circ}$ Figure $2 \mathrm{a}$ ) ${ }^{\circ}$ also ${ }^{\circ}$ produced ${ }^{\circ}$ abundant ${ }^{\circ}$ ions in these spectra that specified the composition of the 6-antenna.

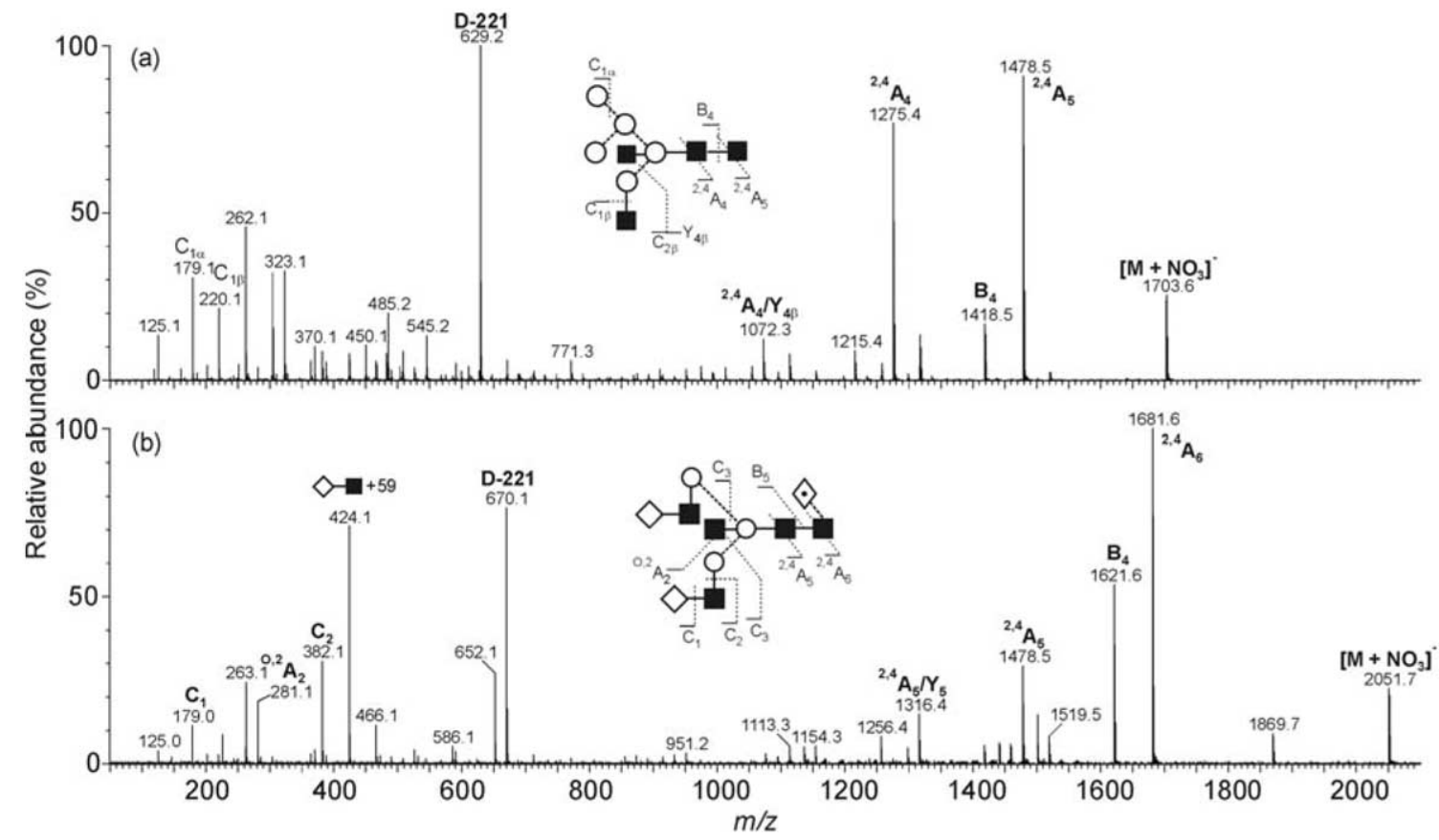

Figure 5. $\mathrm{CID}$ spectrum of the $\left[\mathrm{M}+\mathrm{NO}_{3}\right]^{-}$ion from (a) the hybrid glycan (7) from chicken ovalbumin and (b) the bisected bi-antennary glycan (8). 


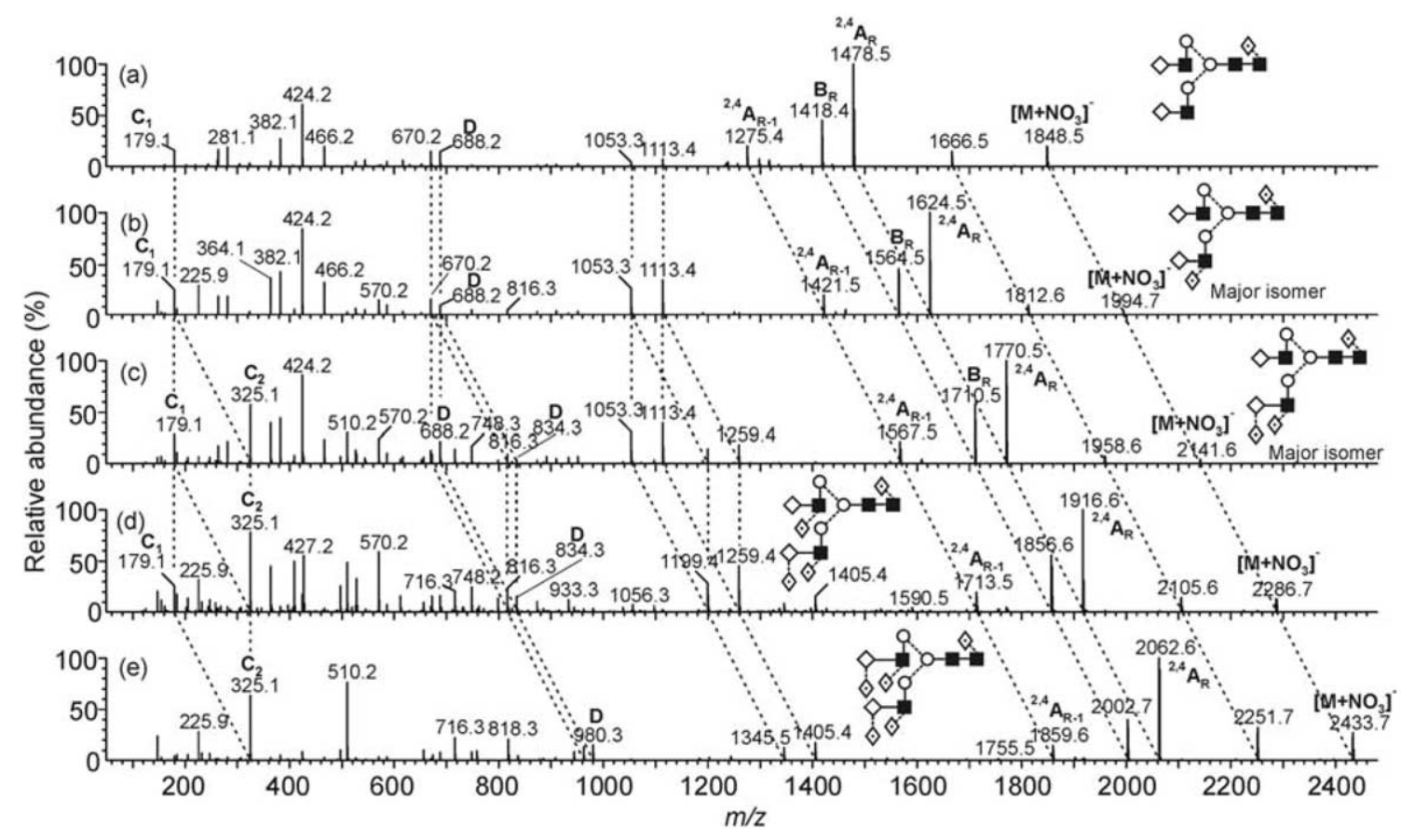

Figure 6. CID spectra of the $\left[\mathrm{M}+\mathrm{NO}_{3}\right]^{-}$ions from bi-antennary glycans carrying from one to five fucose residues (9-13). Broken lines connect ions of the same type.

Prominent A-type cross-ring cleavage ions were formed by cleavage of the mannose residues attached to the GlcNAc residues of the antennas following charge localization on an oxygen atom adjacent to the site of attachment of the GlcNAc such that two carbon atoms from the mannose residue remained in the ion. Thus, the spectra of complex glycans containing Gal $\rightarrow$ GlcNAc antennas exhibited a prominent fragment at $\mathrm{m} / \mathrm{z} 424.1$ (Figures $\left.^{\circ} 2-4\right)^{\circ}$ corresponding $^{\circ}$ to ${ }^{\circ}\left[\mathrm{Gal} \mathrm{GlcNAc}^{\circ}+{ }^{\circ} 59\right]^{-}$ $\left({ }^{1,3} \mathrm{~A}_{3}\right.$ fragment). Substitution by $\alpha$-galactose, as in the glycan ${ }^{\circ}$ from ${ }^{\circ}$ porcine ${ }^{9}$ hyroglobulin $\left(4,{ }^{\circ} \text { Figure } 3 a\right)^{\circ}$ caused a shift of $162 \mathrm{u}$ to $\mathrm{m} / \mathrm{z} 586.1$ whereas fucose substitution $\left(5,{ }^{\circ} \text { Figure }{ }^{\circ} 3 \mathrm{~b}\right)^{\circ}$ produced $^{\circ} \mathrm{a}^{\circ} \mathrm{shift}^{\circ} \mathrm{to}^{\circ} \mathrm{m} / \mathrm{z}$ 570.2. ${ }^{\circ}$ The ${ }^{\circ}$ latter ion demonstrates the stability of fucose in these negative ion spectra in direct contrast to its instability in the spectra ${ }^{\circ}$ of $^{\circ}\left[\mathrm{M}^{\circ}+{ }^{\circ} \mathrm{Na}\right]^{+{ }^{\circ}}$ ions $^{\circ}[30] .{ }^{\circ}$ Where $^{\circ}$ no ${ }^{\circ}$ galactose residue capped the antennas, as in glycans from chicken egg-white ${ }^{\circ}$ glycoprotein $s^{\circ}\left(8^{\circ},{ }^{\circ}\right.$ Figure $\left.{ }^{\circ} 4 a\right),{ }^{\circ}$ this ${ }^{\circ} \mathrm{A}$-type ${ }^{\circ}$ ion appeared at $\mathrm{m} / \mathrm{z} 262$.1. Unlike the situation with several of the other fragment ions, this ion was observed from all antennas, irrespective of the linkage of the GlcNAc residue to the mannose.

\section{Ions Providing Information on the 3-Antenna}

Unlike the spectra of the high-mannose glycans, where the composition of the 3-antenna was determined by subtraction of the masses of the 6-antenna (defined by the $\mathrm{D},[\mathrm{D}-18]$ - and ${ }^{\mathrm{O}, 3} \mathrm{~A}_{3}$ ions), an ion providing information on the 3-antenna was present in the spectra of the complex and hybrid glycans. This ion appeared at $\mathrm{m} / \mathrm{z} 466.2$ in the spectra of the bi-antennary glycans and contained the galactose and GlcNAc residues plus 101 mass units from the 3-mannose residue. In the spectra of the tri-antennary glycans from bovine fetuin, containing a branched 3-antenna, this ion partially shifted to $\mathrm{m} / \mathrm{z} 813.3^{\circ}\left({ }^{\circ},{ }^{\circ} \text { Figure }^{\circ} 2 \mathrm{~b}\right)^{\circ}$ showing ${ }^{\circ}$ that ${ }^{\circ}$ it $^{\circ}$ contained ${ }^{\circ} \mathrm{C} 2$ and $\mathrm{C} 4$ from the mannose residue. Consequently, it must also contain $\mathrm{C} 3$ together with a fourth carbon atom. Ions of this type will be referred to as E-type ions. The ion was prominent in the spectra of the truncated (no galactose) complex and hybrid glycans from hen egg white glycoproteins, $(\mathrm{m} / \mathrm{z} 304$ when one GlcNAc residue ${ }^{\circ}$ was $^{\circ}$ present $^{\circ}\left(7,{ }^{\circ} \text { Figure }^{\circ} 5 \mathrm{a}\right)^{\circ}$ and $^{\circ} \mathrm{m} / z \quad 507^{\circ}$ when there ${ }^{\circ}$ were ${ }^{\circ}$ two,${ }^{\circ}\left(6^{\circ},{ }^{\circ} \text { Figure }^{\circ} 4 a,{ }^{\circ}{ }^{\circ} \text { Table }^{\circ} 2\right)^{\circ}$ confirming ${ }^{\circ}$ its composition. The structure of this ion appears to be as shown in Scheme $\mathbf{1}$ (Ion $d$ ) and a possible mechanism is proposed following formation of a second C-cleavage ion from the $\mathrm{C}_{3}$-ion (Ion $c$ ). The fragmentation of this second C-cleavage ion differs from that of the decomposition ${ }^{\circ}$ ' Ion $\%$ shown in the ${ }^{\circ}$ earlier ${ }^{\circ}$ paper $[18]$ because the oxygen at C-2 carries a sugar residue rather than a hydrogen atom. As noted above, Ion E (Structure $d$ ) was prominent at $\mathrm{m} / \mathrm{z} 831.3$ in the spectrum of the triantennary $^{\circ}$ glycan $^{\circ}$ from $^{\circ}$ bovine $^{\circ}$ fetuin ${ }^{\circ}\left(2,{ }^{\circ}\right.$ Figure $^{\circ} 2 \mathrm{~b}$, branched 3-antenna). In the spectrum of the fucosylated tri-antennary ${ }^{\circ}$ glycan $^{\circ}$ from $^{\circ} \alpha 1$-acid ${ }^{\circ}$ glycoprotein ${ }^{\circ}\left(5,{ }^{\circ}\right.$ Figure $3 b)^{\circ}$ which ${ }^{\circ}$ also ${ }^{\circ}{ }^{\circ}{ }^{\circ}$ obranched 3 -antenna, ${ }^{\circ}$ known ${ }^{\circ}$ to contain an unusual fucose substitution in an antenna rather ${ }^{\circ}$ than $^{\circ}$ on $^{\circ}$ the ${ }^{\circ}$ core $^{\circ} \mathrm{GlcNAc}^{\circ}[26]^{\circ}$, the ${ }^{\circ}$ presence $^{\circ}$ of ${ }^{\circ}$ a prominent ion at $\mathrm{m} / \mathrm{z} 977.4$ and the absence of $\mathrm{m} / \mathrm{z} 831.3$ confirmed the presence of the fucose on the 3- rather than on the 6-antenna.

Although the mass of ion E reflects the composition

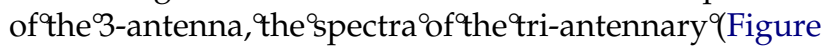




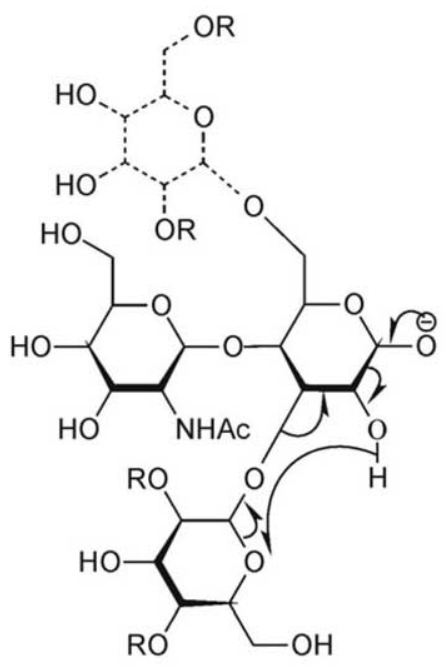

Ion $c$

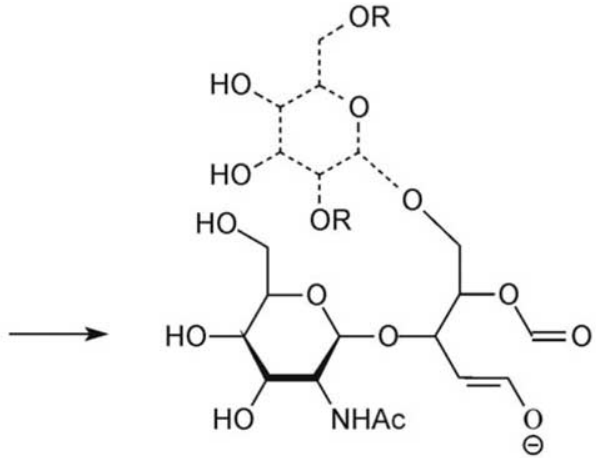

Ion e<smiles>[Y][V]</smiles><smiles>[R]C[C@H]1O[C@H](OC/C(=C\C=C/[O-])OC=O)[C@H](O)[C@H](O)[C@H]1O</smiles>

Ion $f$

Scheme 2. Proposed mechanism for the formation of the ion diagnostic for the presence of a bisecting GlcNAc residue. The source of the hydrogen eliminated during loss of the bisecting GlcNAc residue has not been confirmed.

$2 \mathrm{~b})^{\circ}$ and $^{\circ}$ tetra-antennary ${ }^{\circ}$ glycans $^{\circ}\left(\text { Figure }^{\circ} 2 \mathrm{c}\right)^{\circ}$ also $^{\circ}$ contained an ion at $\mathrm{m} / \mathrm{z} 466.2$, the mass of ion $\mathrm{E}$ in the spectrum $^{\circ}$ of $^{\circ}$ the ${ }^{\circ}$ bi-antennary ${ }^{\circ}$ glycan ${ }^{\circ}\left(\right.$ Figure $\left.^{\circ} 2 \mathrm{a}\right) .^{\circ}$ This ion appears to arise from the 6-antenna and is a consequence of this antenna containing a similar substitution pattern to the bi-antennary glycan, namely a 2-linked GlcNAc residue, thus accounting for its pres- ence $^{\circ}$ in $^{\circ}$ the $^{\circ}$ spectra $^{\circ}$ of ${ }^{\circ}$ the ${ }^{\circ}$ bi- $^{\circ}\left(\text { Figure }^{\circ} 2 \mathrm{a}\right)^{\circ}$ and ${ }^{\circ}$ triantennary $^{\circ}$ (Figure $\left.^{\circ} 2 \mathrm{~b}\right)^{\circ}$ glycans. $^{\circ}$ However, $^{\circ}$ the ${ }^{\circ}$ tetraantennary glycan also contains an ion at this mass. This mass is a consequence of the tetra-antennary containing its second branch at the 6- rather than the 4-position. As discussed above, Ion E contains only carbon atoms 1-4 from the mannose residue and, consequently, Ion

Table 1. Masses and compositions of the D-ion specifying the composition of the 6-antenna of $N$-linked glycans

\begin{tabular}{|c|c|c|c|c|}
\hline$m / z, D$ ion & $m / z$ D-18 & Hexose & HexNAc & Type of glycan \\
\hline 323 & 305 & 1 & 0 & Unprocessed 6-antenna (e.g. $\left.(\mathrm{Man})_{3}(\mathrm{GlcNAc})_{2}\right)$. \\
\hline 485 & 467 & 2 & 0 & High-mannose, Hybrid. \\
\hline 526 & 508 & 1 & 1 & $\begin{array}{l}\text { Truncated (no galactose), unbranched 6- } \\
\text { antenna. }\end{array}$ \\
\hline 647 & 629 & 3 & 0 & High-mannose, Hybrid. \\
\hline 688 & 670 & 2 & 1 & Biantennary, 3-branched triantennary. \\
\hline 729 & 711 & 1 & 2 & Truncated (no galactose), branched 6-antenna. \\
\hline 809 & 791 & 4 & 0 & High-mannose, Hybrid (e.g. (Man) $\left.{ }_{5}(\mathrm{GlcNAc})_{2}\right)$. \\
\hline 891 & 873 & 2 & 2 & $\begin{array}{l}\text { Triantennary (branched 6-antenna), one } \\
\text { galactose. }\end{array}$ \\
\hline 932 & 914 & 1 & 3 & $\begin{array}{l}\text { Truncated (no galactose), branched 6-antenna } \\
\text { with bisected mannose. }\end{array}$ \\
\hline 1053 & 1035 & 3 & 2 & Triantennary (branched 6-antenna). \\
\hline 1094 & 1076 & 2 & 3 & $\begin{array}{l}\text { Branched 6-antenna with bisected mannose } \\
\text { and one galactose. }\end{array}$ \\
\hline
\end{tabular}


Table 2. Masses and compositions of Ion E

\begin{tabular}{cccc}
\hline$m / z$ & Hexose & HexNAc & dHex \\
\hline \hline 304 & 1 & 1 & 0 \\
466 & 2 & 1 & 0 \\
507 & 1 & 2 & 0 \\
669 & 2 & 2 & 0 \\
831 & 3 & 2 & 0 \\
977 & 3 & 2 & 1
\end{tabular}

E from the 6-antenna contains only the 2-branch and appears at $m / z$ 466.2. Differentiation of ion $E$ from each antenna (termed $E_{3}$ and $E_{6}$ from the 3- and 6-antennas, respectively) can be made on the basis of the known structure of the 6-antenna as determined by the masses of the $\mathrm{D}$ and ${ }^{\mathrm{O}, 3} \mathrm{~A}_{4}$ cross-ring cleavage ions. Furthermore, the mass of ion $\mathrm{E}_{6}$ can be used to define the substitution on each branch of the 6-antenna as it only contains the 2-branch.

\section{Ions Revealing Antenna Sequence}

C-ions derived from the non-reducing terminus provided information on antenna sequence, as illustrated for the bi-antennary ${ }^{\circ} \operatorname{glycan}^{\circ}\left(\mathbf{1}^{\circ}{ }^{\circ} \text { Figure }^{\circ} \mathrm{a}\right)^{\circ}$ which $^{\circ}{ }^{\circ}$ ontained ${ }^{\circ} \mathrm{C}^{\circ}$ ions at $m / z 179.1\left(\mathrm{Gal}, \mathrm{C}_{1}\right), 382.2\left(\mathrm{Gal} \rightarrow\right.$ GlcNAc, $_{2}$ ) and 544.3 $\left(\mathrm{Gal} \rightarrow \mathrm{GlcNAc} \rightarrow \mathrm{Man}, \mathrm{C}_{3}\right)$. However, in order to observe the other $\mathrm{C}$-ions, the collision energy had to be reduced in order to avoid their further decomposition. Nevertheless, they were present at low abundance as described earlier [18]..$^{\circ}$ Where $^{\circ}$ antennas $^{\circ}$ of $^{\circ}$ unequal $^{\circ}$ composition $^{\circ}$ were present, $\mathrm{C}$ ions enabled the sequence of both antennas to be $^{\circ}$ traced ${ }^{\circ}$ as $^{\circ}$ shown $^{\circ}$ in ${ }^{\circ}$ Figure 3 .

The $1 \rightarrow$ 4-linkage between the galactose and GlcNAc residues of the antennas of complex glycans was reflected by an ${ }^{\mathrm{O}, 2} \mathrm{~A}_{2}$ cross-ring cleavage of the GlcNAc residue $^{\circ}$ to $^{\circ}$ give $^{\circ}$ the $^{\circ}$ ion $^{\circ}$ at $^{\circ} \mathrm{m} / \mathrm{z} 281.1^{\circ}$ (Figure ${ }^{\circ} 2,{ }^{\circ}$ mecha- nism as in the formation of Ion a, Scheme 1). It partially shifted to $m / z 443$ when an $\alpha$-galactose residue was $\operatorname{present}^{\circ}\left(4,{ }^{\circ}\right.$ Figure $\left.3 a\right)$. Ions $^{\circ}$ were ${ }^{\circ}$ not $^{\circ}$ found ${ }^{\circ}$ that ${ }^{\circ}$ allowed the $\alpha$-Gal $\rightarrow \beta$-Gal linkage to be determined.

\section{Ions Diagnostic for the Presence of a Bisecting GlcNAc Residue}

Figure ${ }^{\circ} \mathrm{a}^{\circ}$ shows $^{\circ}$ the ${ }^{\circ}$ spectrum ${ }^{\circ}$ of ${ }^{\circ}$ the ${ }^{\circ}\left[\mathrm{M}^{\circ}+{ }^{\circ} \mathrm{NO}_{3}\right]^{-}$ion from the hybrid glycan (Man) $)_{5}(\mathrm{GlcNAc})_{4}$ (7) from chicken ovalbumin which was dominated by the ion at $m / z$ 629.2. Corresponding ions were present at $m / z 670.2$ and 914.4 in the spectra of the nitrate adducts of the bisected ${ }^{\circ}$ bi-antennary ${ }^{\circ}$ glycan $^{\circ}\left(8^{\circ}, \text { Figure }^{\circ} 5 \mathrm{~b}\right)^{\circ}$ and ${ }^{\circ}$ pentaantennary ${ }^{\circ} \operatorname{lycan}^{\circ}\left(6^{\circ}{ }^{\circ}\right.$ Figure $\left.^{\circ} 4 a\right)$. ${ }^{\circ}$ This ${ }^{\circ}$ ion ${ }^{\circ}$ quates to ${ }^{\circ}$ that formed by loss of water from the D-ion in the spectra of unbisected glycans. In the high-energy positive ion spectra of $[\mathrm{M}+\mathrm{Na}]^{+}$ions, the equivalent $[\mathrm{D}-\mathrm{GlcNAc}]^{-}$ion has been shown to be diagnostic for the presence of a bisecting GlcNAc residue and to be formed by loss of the bisecting GlcNAc from the $\mathrm{B}_{\mathrm{R}-1}$ ion followed by a

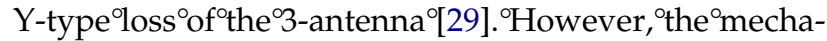
nism in these negative ion spectra appears to be that shown in Scheme 2 to give the D-ion (Ion e) followed by elimination of the allylic GlcNAc residue together with a hydrogen atom from an undetermined position. The $\mathrm{D}$ ion itself (Ion $e$ ) was very weak in these spectra $(\mathrm{m} / \mathrm{z}$ $850.3^{\circ}$ in $^{\circ}$ Figure $\left.\left.^{\circ} 5\right)^{\circ}\right)^{\circ}$ reflecting $^{\circ}$ the $^{\circ}$ ready $^{\circ}$ elimination ${ }^{\circ}$ of the GlcNAc residue. Thus, the absence of, or presence of a very weak $\mathrm{D}$ ion accompanied by a very strong [D $\left.\left(\mathrm{GlcNAc}+\mathrm{H}_{2} \mathrm{O}\right)\right]^{-}$ion indicates the presence of a bisecting GlcNAc residue. This feature is difficult to determine by exoglycosidase digestion because of the absence of a specific exoglycosidase for a bisecting GlcNAc residue.

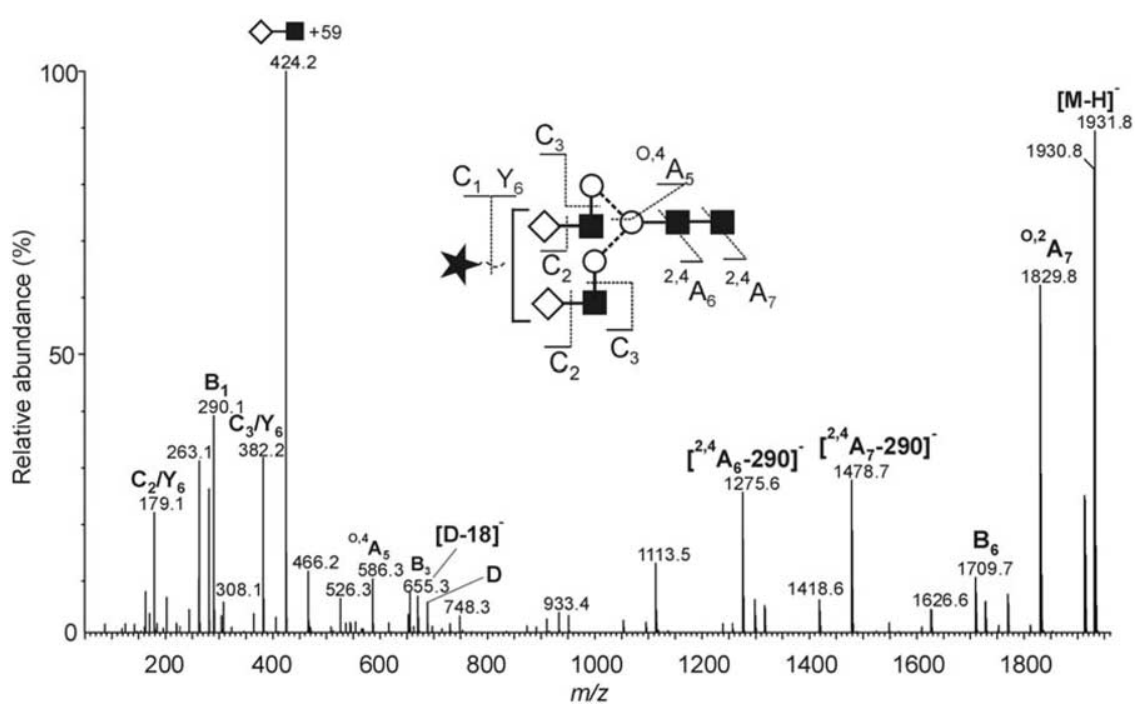

Figure 7. CID spectrum of the $[\mathrm{M}-\mathrm{H}]^{-}$ion from the monosialylated complex bi-antennary glycan (14) from bovine fetuin. Because the antenna to which the sialic acid is linked is not known, both antennas are numbered as if the sialic acid was present. 


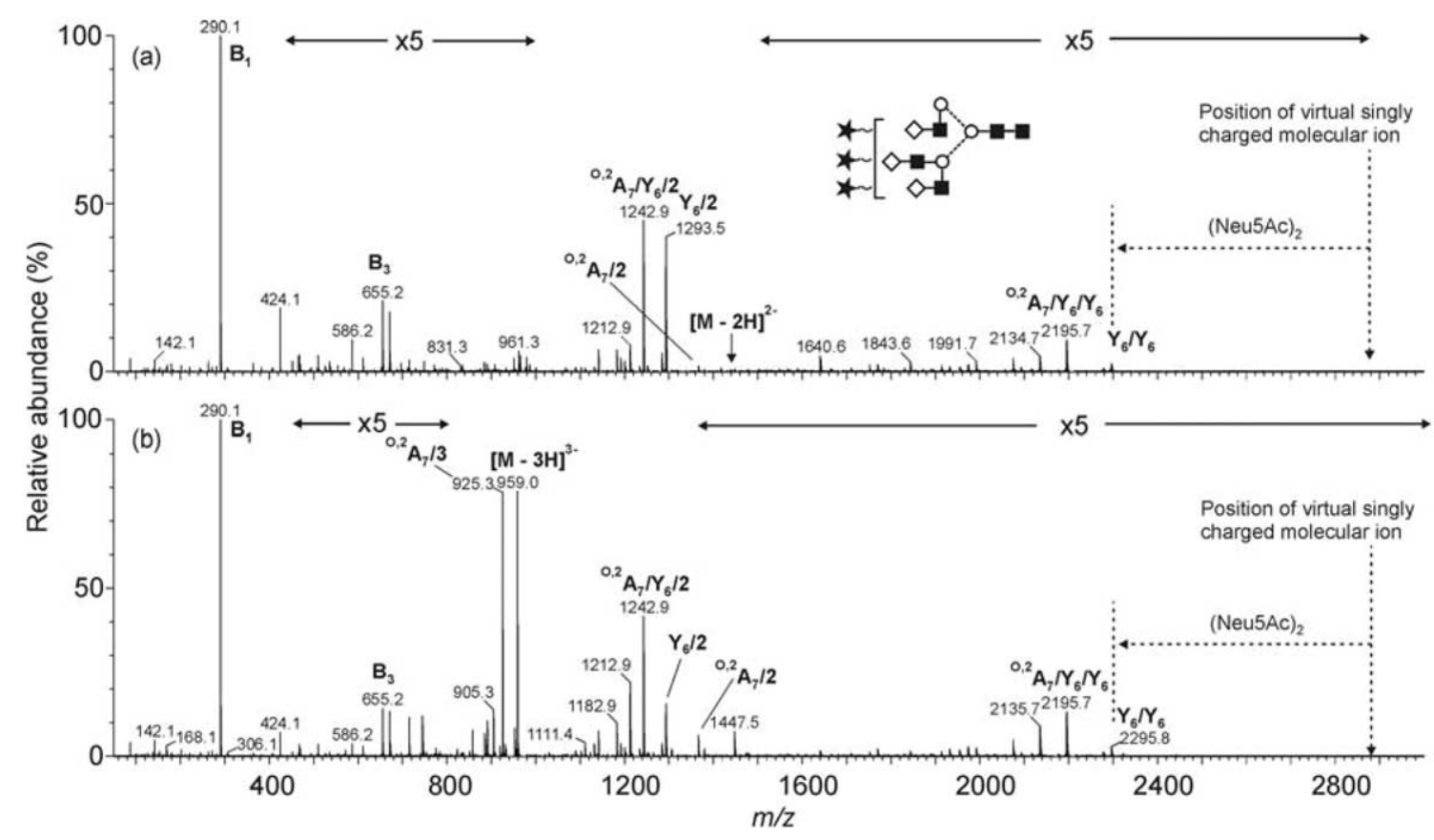

Figure 8. CID spectra of the doubly-charged $\left([\mathrm{M}-2 \mathrm{H}]^{2-}\right)(\mathbf{a})$ and triply-charged $\left([\mathrm{M}-3 \mathrm{H}]^{3-}\right)(\mathbf{b})$ ions from the sialylated tri-antennary glycan (15) from bovine fetuin.

\section{Ions Diagnostic for the Position of Fucose Substitution}

Unlike the situation with positive ion spectra, the antenna-specific ions discussed above largely retained fucose allowing substitution patterns to be determined. Figure ${ }^{\circ}$ shows $^{\circ}$ the ${ }^{\circ}$ spectra ${ }^{\circ}$ of the bi-antennary $^{\circ} \mathrm{N}$-linked glycan $(\mathrm{Gal})_{2}(\mathrm{Man})_{3}(\mathrm{GlcNAc})_{4}$, (2) obtained from human parotid glands substituted with from one to five fucose residues (Compounds 9-13). Their structures have ${ }^{\circ}$ been ${ }^{\circ}$ described ${ }^{\circ}$ earlier ${ }^{\circ}\left[30,{ }^{\circ} 31\right]^{\circ} .^{\circ}$ The $^{\circ}$ spectra ${ }^{\circ}$ of ${ }^{\circ}$ the mono- (9) and penta-fucosylated compounds (13) are from single compounds but the remaining spectra are from mixtures of isomers.

The $^{\circ}$ mono-fucosylated ${ }^{\circ}$ glycan $^{\circ}\left(9,{ }^{\circ} \text { Figure }^{\circ} 6 a\right)^{\circ}$ contains

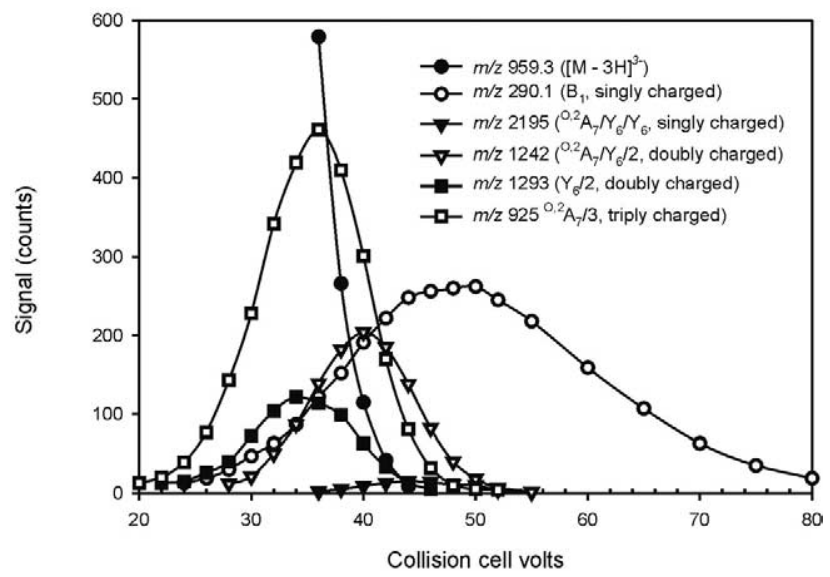

Figure 9. Energy-resolved spectrum for the $[\mathrm{M}-3 \mathrm{H}]^{3-}$ ion from the trisialylated tri-antennary glycan (15) from bovine fetuin. its fucose on the 6-position of the reducing terminal GlcNAc residue giving the prominent losses of 370 $\left({ }^{2,4} \mathrm{~A}_{\mathrm{R}}, \mathrm{m} / \mathrm{z} 1478.5\right), 573\left({ }^{2,4} \mathrm{~A}_{\mathrm{R}-1}, \mathrm{~m} / \mathrm{z} 1275.4\right)$, and $430\left(\mathrm{~B}_{\mathrm{R}}\right.$, $\mathrm{m} / \mathrm{z}$ 1418.3) mass units in the spectra of the nitrate adduct, as discussed above. In the spectra of the other glycans, shifts of the $\mathrm{D}$ and $[\mathrm{D}-18]^{-}$ions were the most diagnostic of the position of fucose substitution. Thus, in the spectra of the di-fucosylated glycan (10, Figure $\left.^{\circ} 6 \mathrm{~b}\right)^{\circ}$ these ${ }^{\circ}$ ions $^{\circ}$ remained $^{\circ}$ largely ${ }^{\circ}$ unshifted $^{\circ}$ with only a small fraction exhibiting a shift from $\mathrm{m} / \mathrm{z}$ 688.2/ 670.2 to $834.3 / 816.3$, showing that the major isomer was substituted on the 3-antenna. The observation that the $\mathrm{C}_{1}$ (galactose) ion at $\mathrm{m} / \mathrm{z} 179.1$ exhibited no shift showed that the fucose was substituted on the GlcNAc residue. The $^{\circ}$ trifucosylated ${ }^{\circ}$ glycan $^{\circ}\left(\mathbf{1 1},{ }^{\circ} \text { Figure }^{\circ} 6 \mathrm{c}\right)^{\circ}$ also ${ }^{\circ}$ exhibited little shift in the D and [D - 18] $]^{-}$ions consistent with the reported major structure that has a core fucose and two ${ }^{\circ}$ fucose ${ }^{\circ}$ residues ${ }^{\circ}$ on $^{\circ}$ the ${ }^{\circ} 3$-antenna ${ }^{\circ}[31]^{\circ}$ The $^{\circ}$ appearance of an abundant $C_{1}$ ion at $\mathrm{m} / \mathrm{z} 325.1$ confirmed substitution of the third fucose residue on the galactose. In $^{\circ}$ the $^{\circ}$ spectrum $^{\circ}$ of $^{\circ}$ the $^{\circ}$ tetrafucosylated ${ }^{\circ}$ glycan $^{\circ}(\mathbf{1 2}$, Figure ${ }^{\circ} 6 \mathrm{~d}$ ), ${ }^{\circ}$ the ${ }^{\circ} \mathrm{C}_{2}$ ion appeared at $\mathrm{m} / \mathrm{z} 528.2$ and 674.2 , corresponding to antennas containing one and two fucose residues respectively. However, there was an abundant $\left[\mathrm{C}_{2}-164\right]^{-}$ion $(\mathrm{m} / \mathrm{z} 364.2)$ corresponding to the $\left[\mathrm{C}_{2}-\mathrm{H}_{2} \mathrm{O}\right]^{-}$ion in the spectrum of the unfucosylated glycan and, therefore, formed by loss of a fucose molecule. As substituents linked to the 3-position of GlcNAc $^{\circ}$ are $^{\circ} \mathrm{known}^{\circ}$ to $^{\circ} \mathrm{be}^{\circ}$ preferentially $^{\circ}$ eliminated ${ }^{\circ}[32$ 36], ${ }^{\circ}$ this ${ }^{\circ}$ observation ${ }^{\circ}$ can $^{\circ}$ be $^{\circ}$ used $^{\circ}$ to $^{\circ}$ demonstrate $^{\circ}$ the presence of a fucose residue in this position. The $\left[\mathrm{C}_{2}-\right.$ fucose $]^{-}$ion appeared at $\mathrm{m} / \mathrm{z} 510.2 .1$ in the spectrum of the ${ }^{\circ}$ pentafucosylated ${ }^{\circ}$ glycan $\left.^{\circ}\left(13^{\circ}{ }^{\circ} \text { Figure }^{\circ} 6\right)^{\circ}\right)^{\circ}{ }^{\circ}$ this 


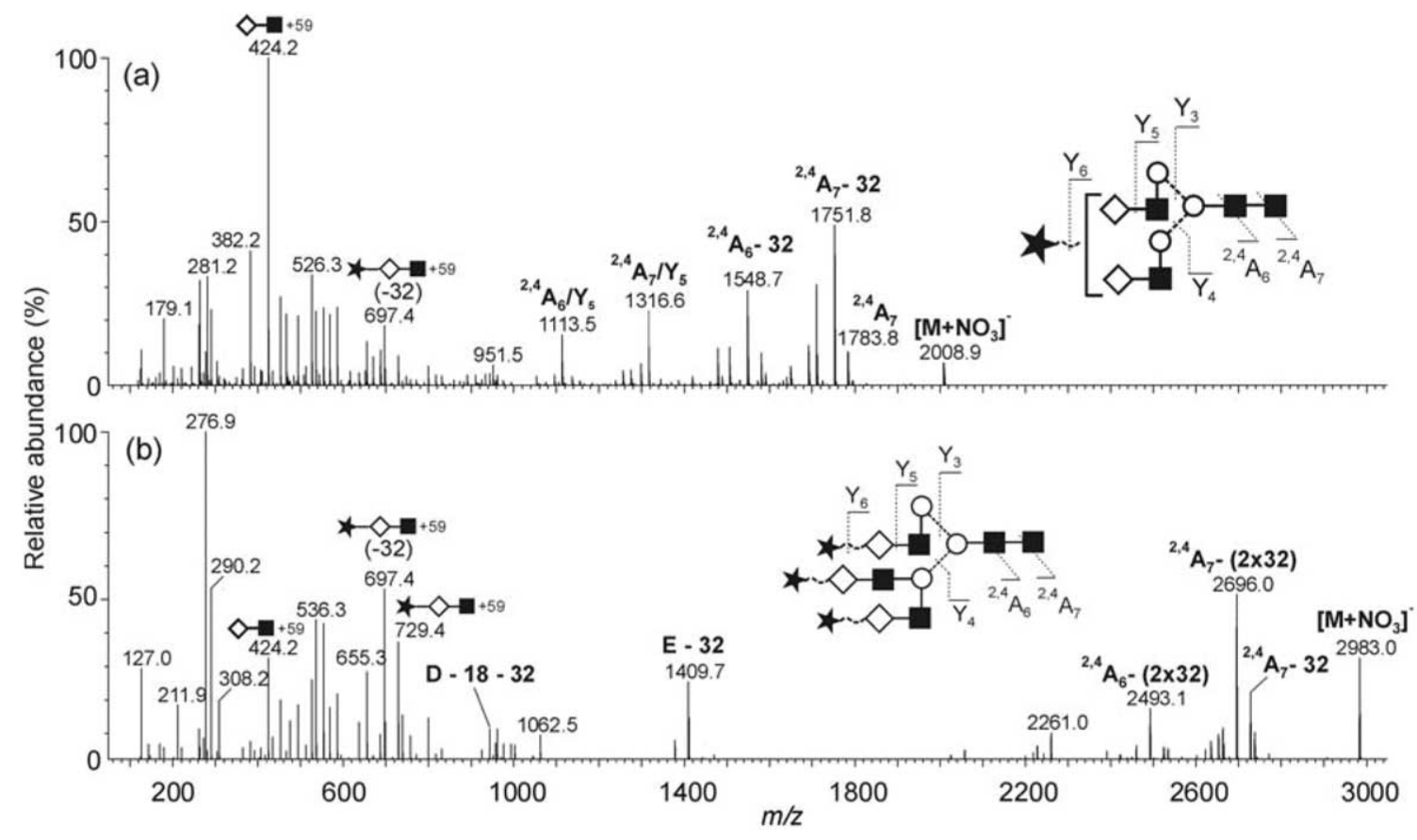

Figure 10. CID spectrum of the nitrate adducts of the methyl esters of (a) the monosialylated bi-antennary glycan (14) and (b) the disialylated tri-antennary glycan.

compound contained two antennas substituted with fucose at the 3-position of GlcNAc.

Ions corresponding to loss of Gal $\rightarrow$ GlcNAc from the $[\mathrm{M}-\mathrm{H}-161]^{-}$and $\mathrm{B}_{\mathrm{R}}$ ions of the nitrate adducts also reflected the distribution of the fucose residue on the antennas. Thus, in the spectrum of the difucosylated glycan ${ }^{\circ}\left(10,{ }^{\circ}\right.$ Figure $\left.^{\circ} 6 \mathrm{~b}\right),{ }^{\circ}$ shown ${ }^{\circ}$ to ${ }^{\circ}{ }^{\circ}{ }^{\circ}$ fucosylated ${ }^{\circ}$ mainly on the 3-antenna, these ions largely remained at $\mathrm{m} / \mathrm{z}$ 1113.3 and 1053.3 , respectively showing that they were products of the loss of the 3- rather than the 6-antenna. Their shifts and relative abundance in the other three spectra $^{\circ}\left(\text { Figure }^{\circ} 6 \mathrm{c}-\mathrm{Q}\right)^{\circ}$ paralleled $^{\circ}$ that ${ }^{\circ}$ of ${ }^{\circ}$ the ${ }^{\circ} \mathrm{D}^{\circ}$ and ${ }^{\circ}\left[\mathrm{D}^{\circ}-\right.$ $18]^{-}$ions, and are, therefore, also indicative of the substitution pattern of the fucose residues. The mechanisms forming these ions are unclear as they appear to involve loss of the reducing-terminal GlcNAc residue $\left(B_{R}\right.$ ion) or a fragment of it $\left({ }^{2,4} A_{R}\right.$ ion) together with a specific loss of the 3-antenna. Electron shifts through the sugar rings linking these sites are not possible without initiating glycosidic cleavages and, therefore, the presence of these specific cleavages suggests the occurrence of a specific hydrogen transfer to either the fragment formed at the reducing terminal from the 3 -antenna or vice versa in a similar manner to the proposed losses of mannose residues from the ${ }^{2,4} \mathrm{~A}_{\mathrm{R}-1}$ ion $^{\circ}$ discussed ${ }^{\circ}{ }^{\circ}{ }^{\circ}$ reference ${ }^{\circ}[18]$.

\section{Fragmentation of Doubly-Charged Ions}

from Neutral Glycans

The $\left[\mathrm{M}+\left(\mathrm{NO}_{3}\right)_{2}\right]^{2+}$ ions from the complex and hybrid glycans fragmented exclusively to singly-charged fragments that mirrored the fragment ions seen in the spectra of the singly-charged $\left[\mathrm{M}+\mathrm{NO}_{3}\right]^{-}$ions as shown ${ }^{\circ}$ for ${ }^{\circ}$ the $e^{\circ}$ truncated ${ }^{\circ}$ penta-antennary ${ }^{\circ}$ glycan ${ }^{\circ} 6$ (Figure $\left.^{\circ} 4\right) .{ }^{\circ}$ Thus, ${ }^{\circ}$ because ${ }^{\circ}$ there ${ }^{\circ}$ was $^{\circ}$ sometimes ${ }^{\circ} a^{\circ}$ tendency for the larger glycans to form doubly-charged ions in preference to singly-charged ions, the singly-charged fragmentation spectrum could easily be obtained.

\section{Fragmentation of Sialylated Glycans}

Underivatized glycans. The monosialylated complex glycans fragmented in a similar manner to the neutral compounds in that they produced the same $\mathrm{C}, \mathrm{D}$, and $\mathrm{E}$ ions and a prominent ion corresponding to [Gal $\rightarrow$ GlcNAc +59$]^{-}\left(\left[\left[^{1,3} \mathrm{~A}_{3}-\mathrm{Neu} 5 \mathrm{Ac}\right]^{-}, \mathrm{m} / z\right.\right.$ 424.2) as exemplified by the spectrum of the monosialylated bi-antennary ${ }^{\circ}$ glycan $^{\circ}\left(\mathbf{1 4},{ }^{\circ}\right.$ Figure $\left.{ }^{\circ}\right) .{ }^{\circ}$ However, ${ }^{\circ}$ the upper mass region was different. The ion formed by loss of 161 mass units $\left(\mathrm{m} / \mathrm{z} 1769.7,{ }^{2,4} \mathrm{~A}_{\mathrm{R}}\right)$, prominent in the spectra of the neutral glycans, was weak due to a further loss of sialic acid which gave the ion at $m / z 1478.5\left({ }^{2,4} \mathrm{~A}_{R} / \mathrm{Y}_{\mathrm{NR}}\right)$. Similarly the ${ }^{2,4} A_{R-1}$ ion was replaced by a ${ }^{2,4} A_{R-1} / Y_{N R}$ fragment at $m / z$ 1275.5). There was a weak $\boldsymbol{B}_{\mathbf{R}}$ ion $(\mathrm{m} / \mathrm{z}$ 1709.6) but an abundant ion formed by loss of 101 mass units $\left(\mathrm{HO}-\mathrm{CH}=\mathrm{CH}-\mathrm{NHAc},{ }^{\mathrm{O}, 2} \mathrm{~A}_{\mathrm{R}}\right.$ or possibly a ${ }^{3,5} \mathrm{X}_{\mathrm{NR}}$ cleavage). $A B_{N R}$ cleavage gave the sialic acid residue ion at $m / z 290.1$.

Figure ${ }^{\circ} 8^{\circ}$ shows $^{\circ}$ the ${ }^{\circ} \mathrm{CID}^{\circ}$ spectra $^{\circ}$ of ${ }^{\circ}$ the ${ }^{\circ}$ doubly- ${ }^{\circ}$ and triply-charged ions from the trisialylated tri-antennary glycan $^{\circ}(15),{ }^{\circ}$ and $^{\circ}$ Figure $^{\circ} 9^{\circ}$ shows $^{\circ}$ how $^{\circ}$ the ${ }^{\circ}$ abundance ${ }^{\circ}$ of the fragment ions varied with collision cell energy. The doubly-charged ${ }^{\circ}$ ion $^{\circ}\left(\mathrm{m} / \mathrm{z} \text { 1438.5, }{ }^{\circ} \text { Figure }^{\circ} 8 \mathrm{a}\right)^{\circ}$ showed $^{\circ} \mathrm{a}$ pattern of doubly-charged fragments that mirrored the upper mass range of the singly-charged ion from the 


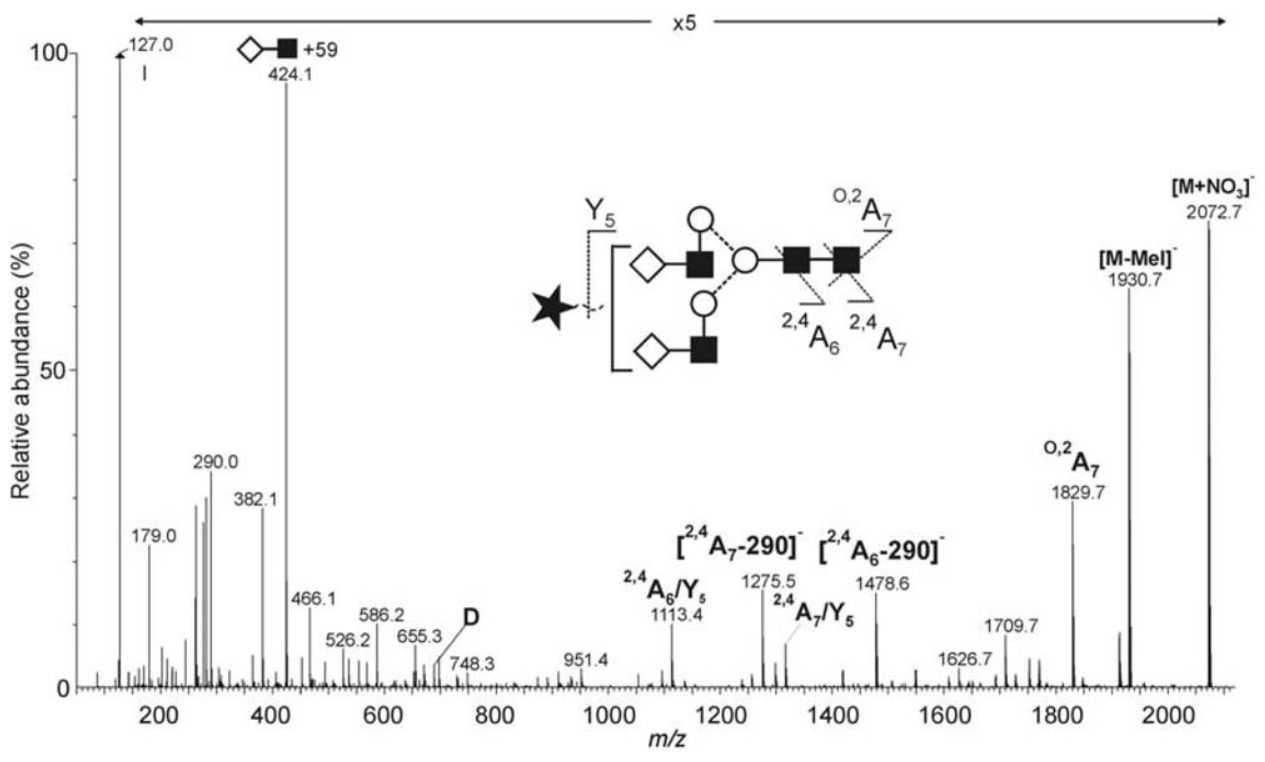

Figure 11. CID spectrum of the iodide adduct of the methyl ester of the monosialylated bi-antennary glycan (14).

monosialylated glycan, namely ${ }^{0,2} \mathrm{~A}_{R}$ and ${ }^{2,4} \mathrm{~A}_{\mathrm{R}}$ cleavages and losses from them of a further sialic acid residue (Y-cleavage). Singly-charged fragments were formed by loss of a sialic acid residue with its charge and reflected the pattern of singly-charged ions from the $[\mathrm{M}-\mathrm{H}]^{-}$ion. An abundant D-fragment at $\mathrm{m} / \mathrm{z} 961.4$ reflected the sialylated 6-antenna but the sialylated ion from the 3-antenna (E-type fragment), expected at $\mathrm{m} / \mathrm{z}$ 1413 , was missing. However, their desialylated counterparts ${ }^{\circ}$ were ${ }^{\circ}$ present $^{\circ}$ at $^{\circ} \mathrm{m} / z 831^{\circ}$ and $^{\circ} 446^{\circ}$ (Tables ${ }^{\circ} 1^{\circ}$ and 2).

The triply-charged ion from the trisialylated, triantennary glycan from bovine fetuin $(\mathrm{m} / \mathrm{z}$ 958.7, 15, Figure $8 \mathrm{~b})^{\circ}{ }^{\circ}$ gave ${ }^{\circ}{ }^{\circ}$ spectrum ${ }^{\circ}$ that ${ }^{\circ}{ }^{\circ}$ as $^{\circ}$ almost ${ }^{\circ}$ identical ${ }^{\circ}$ to that ${ }^{\circ}$ reported $^{\circ}$ by $^{\circ}$ Sagi $^{\circ}$ et $^{\circ}$ al. $^{\circ}[16]^{\circ}$ from $^{\circ}$ erythropoietin even though it was branched on the 3-linked antenna, whereas the reported spectrum came from a tri-antennary glycan that was branched on the 6-antenna. The most abundant ions were formed by the above reducing-end fragments as singly-, doubly- and triplycharged fragments, the singly- and doubly-charged fragments were the result of loss of two sialic acid residues with two and one charge, respectively. Although the arm-specific fragment ions were very weak or missing, a prominent singly-charged $\mathrm{B}_{3}\left(\mathrm{~B}_{\mathrm{NR}-2}\right)$ fragment at $m / z 655$ ([Neu5Ac-Gal-GlcNAc $-\mathrm{H}]^{-}$) reflected the composition of the sialylated antennas. A similar spectrum was recorded from the disialylated bi-antennary glycan but with the addition of a prominent singly-charged $\mathrm{C}_{4}$ ion at $\mathrm{m} / \mathrm{z} 835$. The corresponding ion was absent from the spectrum of the monosialylated glycan (singly-charged).

The linkage of the sialic acids could sometimes be determined from the presence or absence of several of the singly-charged ions as described in our earlier publication ${ }^{\circ}[10] .{ }^{\circ}$ Thus $^{\circ}{ }^{\circ}$ the ${ }^{\circ}$ presence $^{\circ}$ of $^{\circ}$ an $^{\circ}$ ion $^{\circ}$ at ${ }^{\circ} \mathrm{m} / z$ $306.1\left({ }^{\mathrm{O}, 4} \mathrm{~A}_{2}-\mathrm{CO}_{2}\right)$ indicated an $\alpha 2 \rightarrow$ 6-linked sialic acid. Its relatively low abundance in the spectra of the sialylated ${ }^{\circ}$ glycans $^{\circ}$ from $^{\circ}$ bovine $^{\circ}$ fetuin ${ }^{\circ}$ (Figures ${ }^{\circ} 7^{\circ}$ and $8),{ }^{\circ}$ compared $^{\circ}$ with $^{\circ}$ its $^{\circ}$ abundance ${ }^{\circ}$ in $^{\circ}$ the ${ }^{\circ}$ reported spectrum of the synthetic bi-antennary glycan with two ${ }^{\circ} \alpha 2^{\circ} \rightarrow{ }^{\circ} 6$-linked ${ }^{\circ}$ sialic ${ }^{\circ}$ acid ${ }^{\circ}$ residues ${ }^{\circ}[10]^{\circ}$ suggested that both $\alpha 2 \rightarrow 3$ - and $\alpha 2 \rightarrow 6$-linked sialic acids were present. This conclusion was supported by the ions at $\mathrm{m} / \mathrm{z} 655.2\left(\mathrm{~B}_{3}\right)$ and 671.2 , whose relative abundance also appears to be a function of the sialic acid linkage.

\section{Methyl Esters}

Formation of the methyl esters of the sialic acids by the ${ }^{\circ}$ method $^{\circ}$ described $^{\circ}$ by $^{\circ}$ Powell $^{\circ}$ and $^{\circ}$ Harvey $^{\circ}$ [27] produced spectra similar to those of the neutral glycans because the charge again resided on hydroxy rather than acid groups. However, the spectra were complicated by ready losses of methanol from many of the diagnostic fragment ions that contained the derivatized ${ }^{\circ}$ sialic $^{\circ}$ acid $^{\circ}$ (Figure 10$)$. ${ }^{\circ}$ Thus, ${ }^{\circ}$ for ${ }^{\circ}$ example, in the spectrum of the monosialylated bi-antennary glycan, the ${ }^{2,4} A_{R},{ }^{2,4} A_{R-1}, B_{R},{ }^{2,4} A_{R} / Y_{6},{ }^{2,4} A_{R-1} / Y_{6}$, and [D -18$]^{-}$ions were largely replaced by their analogues ${ }^{\circ}$ that $^{\circ}$ had $^{\circ}$ lost $^{\circ}$ methanol $^{\circ}$ (Figure ${ }^{\circ}$ 10a). ${ }^{\circ}$ The spectrum of the nitrate analogue of the methylated disialylated 9 tri-antennary ${ }^{\circ}$ glycan ${ }^{\circ}$ hown in ${ }^{\circ}$ Figure $10 \mathrm{~b}$ shows losses of one and two molecules of methanol from these ions. The E-type ions defining the location of one and two sialic acid residues show losses of one methanol molecule for the ion containing one sialic acid residue $(\mathrm{m} / \mathrm{z} 1136.5$ and 1104.5$)$ and both one $(\mathrm{m} / \mathrm{z}$ 1409.7) and two $(\mathrm{m} / \mathrm{z}$ 1377.6) molecules for the disialylated analogue.

The MS ${ }^{1}$ spectrum of the methyl esters contained abundant $[\mathrm{M}+\mathrm{I}]^{-}$ions as the result of the presence of 


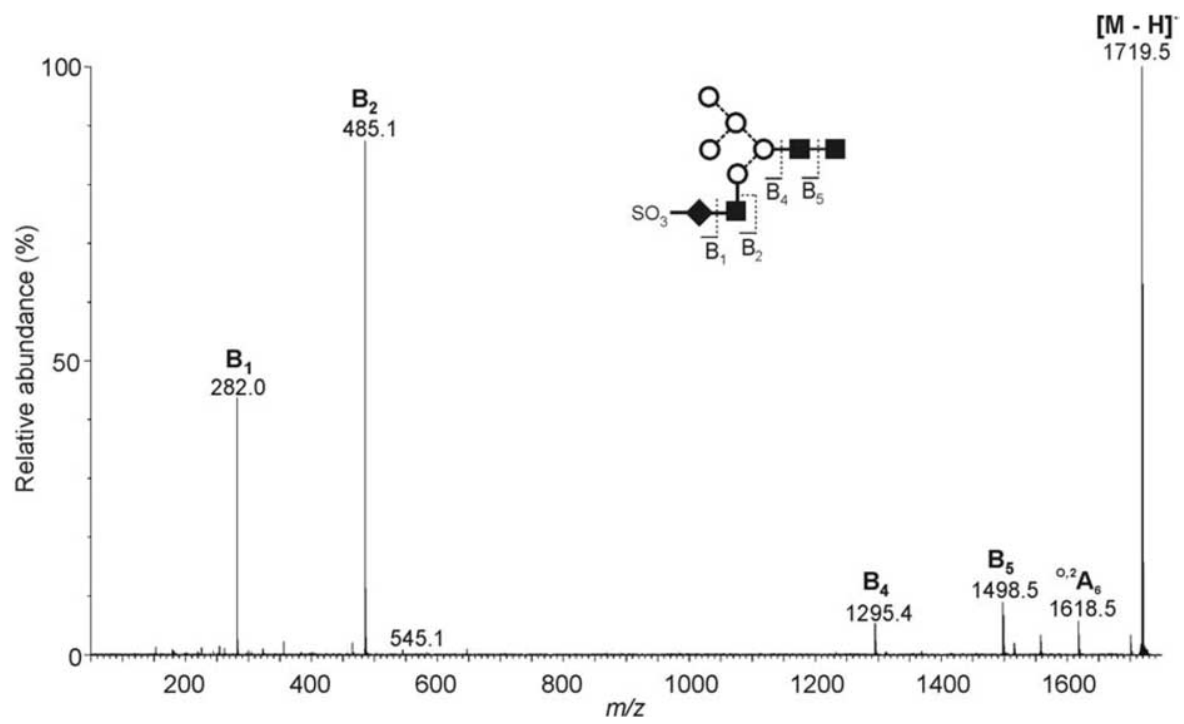

Figure 12. CID spectrum of the sulfated hybrid glycan (16) from equine luteinizing hormone.

residual iodine from the reaction with methyl iodide. These adducts showed weak fragmentation as de-

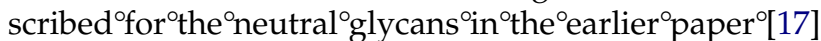
but with some differences from that of the nitrate adducts. Ions in the high-mass region were dominated by the loss of MeI to give the equivalent of the [M $\mathrm{H}]^{-}$ion which then fragmented in a similar manner to the $[\mathrm{M}-\mathrm{H}]^{-}$ions from the underivatized glycans (Figure ${ }^{\circ 11}$ ).

\section{Fragmentation of Sulfated Glycans}

Sulfated glycans showed a different fragmentation pattern as illustrated by the spectrum of the $\left[\mathrm{M}-\mathrm{H}^{-}\right.$ion from the hybrid ${ }^{\circ}$ glycan $^{\circ}\left(16,{ }^{\circ}\right.$ Figure 12$) .{ }^{\circ}$ Charge 'retention on the sulfate group gave abundant $B_{N R}$ and $B_{N R-1}$ cleavages adjacent to the two HexNAc residues of the 3 -antenna to produce the major ions at $\mathrm{m} / \mathrm{z} 282.0$ and 485.0. The only other significant ions were ${ }^{\mathrm{O}, 2} \mathrm{~A}_{\mathrm{R}}(\mathrm{m} / \mathrm{z}$ 1618.5), ${ }^{2,4} \mathrm{~A}_{\mathrm{R}}(\mathrm{m} / \mathrm{z} 1558.5), \mathrm{B}_{\mathrm{R}}(\mathrm{m} / \mathrm{z} 1498.5)$, and $\mathrm{B}_{\mathrm{R}-1}(\mathrm{~m} / \mathrm{z}$ 1295.4)

\section{Summary and Conclusions}

Fragmentation of the hybrid and complex glycans followed the same general pattern as fragmentation of the high-mannose glycans; formation of most ions could be rationalized by initial abstraction of a proton from one specific hydroxy group. C-type glycosidic and crossring fragments dominated the spectra with ${ }^{2,4} \mathrm{~A}_{\mathrm{R}}$ and ${ }^{2,4} \mathrm{~A}_{\mathrm{R}-1}$ ions defining the structure of the fucosylated and non-fucosylated core. The stability of most cross-ring fragments appeared to be the result of the formation of an ionized enol structure. Formation of a $\mathrm{C}_{\mathrm{R}-2}$ ion appeared to be a prerequisite to production of many of the other fragment ions.

Additional specific information that was revealed by these negative ion spectra included the sequence of the antennas (C-fragments), the composition of the individual antennas (D and $\mathrm{E}$ fragments from the 6-, and both 6 and 3-antennas, respectively, and ${ }^{0,3} \mathrm{~A}$ fragment of the branching mannose residue), the presence or absence of a bisecting GlcNAc residue ([D $-221]^{-}$ion) and the position of substituents such of fucose on the antennas. These ions were the result of the more specific nature of the fragmentation of the negative ions compared with that of the corresponding positive ions and provided specific structural information that was not extractable from the positive ion spectra or from classical experiments involving exoglycosidase digestions.

\section{Acknowledgments}

The author thanks Professor R. A. Dwek, Director of the Glycobiology Institute, for his help and encouragement and Dr. George R. Bousfield for permission to include the result from the sulfated glycan. The author is grateful to one of the reviewers who pointed out that ion E could arise from the 6- as well as the 3-antenna. He also thanks the Wellcome Trust for an equipment grant to purchase the Q-TOF mass spectrometer.

\section{References}

1. Varki, A. Biological roles of oligosaccharides: All of the theories are correct. Glycobiology 1993, 3, 97-130.

2. Dwek, R. A. Glycobiology: Towards understanding the function of sugars. Chem. Rev. 1996, 96, 683-720.

3. Dwek, R. A.; Edge, C. J.; Harvey, D. J.; Wormald, M. R.; Parekh, R. B. Analysis of glycoprotein-associated oligosaccharides. Ann. Rev. Biochem. 1993, 62, 65-100.

4. Rudd, P. M.; Dwek, R. A. Rapid, sensitive sequencing of oligosaccharides from glycoproteins. Curr. Opin. Biotechnol. 1997, 8, 488-497.

5. Rudd, P. M.; Guile, G. R.; Küster, B.; Harvey, D. J.; Opdenakker, G.; Dwek, R. A. Oligosaccharide sequencing technology. Nature 1997, 388, 205-207.

6. Rudd, P. M.; Colominas, C.; Royle, L.; Murphy, N.; Hart, E.; Merry, A. H.; Hebestreit, H. F.; Dwek, R. A. A high-perfor- 
mance liquid chromatography based strategy for rapid, sensitive sequencing of N-linked oligosaccharide modifications to proteins in sodium dodecyl sulphate polyacrylamide electrophoresis gel bands. Proteomics 2001, 1, 285-294.

7. Sutton, C. W.; O'Neill, J. A.; Cottrell, J. S. Site-specific characterization of glycoprotein carbohydrates by exoglycosidase digestion and laser desorption mass spectrometry. Anal. Biochem. 1994, 218, 34-46.

8. Harvey, D. J.; Rudd, P. M.; Bateman, R. H.; Bordoli, R. S.; Howes, K.; Hoyes, J. B.; Vickers, R. G. Examination of complex oligosaccharides by matrix-assisted laser desorption/ionization mass spectrometry on time-of-flight and magnetic sector instruments. Org. Mass Spectrom. 1994, 29, 753-765.

9. Zaia, J. Mass spectrometry of oligosaccharides. Mass Spectrom. Rev. 2004, 23, 161-227.

10. Wheeler, S. F.; Harvey, D. J. Negative ion mass spectrometry of sialylated carbohydrates: Discrimination of $\mathrm{N}$-acetylneuraminic acid linkages by matrix-assisted laser desorption/ionization-time-of-flight and electrospray-time-of-flight mass spectrometry. Anal. Chem. 2000, 72, 5027-5039.

11. Chai, W.; Piskarev, V.; Lawson, A. M. Negative-ion electrospray mass spectrometry of neutral underivatized oligosaccharides. Anal. Chem. 2001, 73, 651-657.

12. Pfenninger, A.; Karas, M.; Finke, B.; Stahl, B. Structural analysis of underivatized neutral human milk oligosaccharides in the negative ion mode by nano-electrospray $\mathrm{MS}^{\mathrm{n}}$; Part 1 . Methodology. J. Am. Soc. Mass Spectrom. 2002, 13, 1331-1340.

13. Pfenninger, A.; Karas, M.; Finke, B.; Stahl, B. Structural analysis of underivatized neutral human milk oligosaccharides in the negative ion mode by nano-electrospray $\mathrm{MS}^{\mathrm{n}}$; Part 2. Application to isomeric mixtures. J. Am. Soc. Mass Spectrom. 2002, 13, 1341-1348.

14. Chai, W.; Piskarev, V.; Lawson, A. M. Branching pattern and sequence analysis of underivatized oligosaccharides by combined MS/MS of singly and doubly charged molecular ions in negative-ion electrospray mass spectrometry. J. Am. Soc. Mass Spectrom. 2002, 13, 670-679.

15. Quéméner, B.; Désiré, C.; Lahaye, M.; Debrauwer, L.; Negroni, L. Structural characterization of both positive- and negativeion electrospray mass spectrometry of partially methyl-esterified oligogalacturonides purified by semi-preparative highperformance anion-exchange chromatography. Eur. J. Mass. Spectrom. 2003, 9, 45-60.

16. Sagi, D.; Peter-Katalinic, J.; Conradt, H. S.; Nimtz, M. Sequencing of tri- and tetra-antennary $\mathrm{N}$-glycans containing sialic acid by negative mode ESI QTOF tandem MS. J. Am. Soc. Mass Spectrom. 2002, 13, 1138-1148.

17. Harvey, D. J. Fragmentation of negative ions from carbohydrates; Part 1. Use of nitrate and other anionic adducts for the production of negative ion electrospray spectra from $N$-linked carbohydrates. J. Am. Soc. Mass Spectrom. 2005, 16, 622-630.

18. Harvey, D. J. Fragmentation of negative ions from carbohydrates; Part 2. Fragmentation of high-mannose $N$-linked glycans. J. Am. Soc. Mass Spectrom. 2005, 16, 631-646.

19. Patel, T.; Bruce, J.; Merry, A.; Bigge, C.; Wormald, M.; Jaques, A.; Parekh, R. Use of hydrazine to release in intact and unreduced form both $\mathrm{N}$ - and O-linked oligosaccharides from glycoproteins. Biochemistry 1993, 32, 679-693.

20. Wing, D. R.; Field, M. C.; Schmitz, B.; Thor, G.; Dwek, R. A.; Schachner, M. S.; Rademacher, T. W. The use of large-scale hydrazinolysis in the preparation of $\mathrm{N}$-linked oligosaccharide libraries: Application to brain tissue. Glycoconj. J. 1992, 9, 293-301.

21. de Waard, P.; Koorevaar, A.; Kamerling, J. P.; Vliegenthart, J. F. G. Structure determination by ${ }^{1} \mathrm{H}$ NMR spectroscopy of (sulfated) sialylated $\mathrm{N}$-linked carbohydrate chains released from porcine thyroglobulin by peptide- $N^{4}$-( $N$-acetyl- $\beta$-glucosaminyl)asparagine amidase-F. J. Biol. Chem. 1991, 266, 4237-4243.

22. Kamerling, J. P.; Rijkse, I.; Maas, A. A. M.; van Kuik, J. A.; Vliegenthart, J. F. G. Sulfated $N$-linked carbohydrate chains in porcine thyroglobulin. FEBS Letts. 1988, 241, 246-250.

23. Da Silva, M. L. C.; Stubbs, H. J.; Tamura, T.; Rice, K. G. ${ }^{1} \mathrm{H}-\mathrm{NMR}$ characterization of a hen ovalbumin tyrosinamide N-linked oligosaccharide library. Arch. Biochem. Biophys. 1995, 318, 465-475.

24. Harvey, D. J.; Wing, D. R.; Küster, B.; Wilson, I. B. H. Composition of $\mathrm{N}$-linked carbohydrates from ovalbumin and co-purified glycoproteins. J. Am. Soc. Mass Spectrom. 2000, 11, $564-571$.

25. Green, E. D.; Adelt, G.; Baenziger, J. U.; Wilson, S.; van Halbeek, H. The asparagine-linked oligosaccharides on bovine fetuin. Structural analysis of N-glycanase-released oligosaccharides by 500 -Megahertz 1H-NMR spectroscopy. J. Biol. Chem. 1988, 263, 18253-18268.

26. Fournet, B.; Montreuil, J.; Strecker, G.; Dorland, L.; Haverkamp, J.; Vliegenthart, J. F. G.; Binette, J. P.; Schmid, K. Determination of the primary structures of 16 asialo-carbohydrate units derived from human plasma $\alpha 1$-acid glycoprotein by $360 \mathrm{MHz}{ }^{1} \mathrm{H}$ NMR spectroscopy and permethylation analysis. Biochemistry 1978, 17, 5206-5214.

27. Powell, A. K.; Harvey, D. J. Stabilization of sialic acids in $\mathrm{N}$-linked oligosaccharides and gangliosides for analysis by positive ion matrix-assisted laser desorption-ionization mass spectrometry. Rapid Commun. Mass Spectrom. 1996, 10, 1027-1032.

28. Domon, B.; Costello, C. E. A systematic nomenclature for carbohydrate fragmentations in FAB-MS/MS spectra of glycoconjugates. Glycoconj. J. 1988, 5, 397-409.

29. Harvey, D. J.; Martin, R. L.; Jackson, K. A.; Sutton, C. W. Fragmentation of $N$-linked glycans with a MALDI-ion trap time-of-flight mass spectrometer. Rapid Commun. Mass Spectrom. 2004, 18, 2997-3007.

30. Guile, G. R.; Harvey, D. J.; O’Donnell, N.; Powell, A. K.; Hunter, A. P.; Zamze, S.; Fernandes, D. L.; Dwek, R. A.; Wing, D. R.Identification of highly fucosylated N-linked oligosaccharides from the human parotid gland. Eur. J. Biochem. 1998, 258, 623-656.

31. Gillece-Castro, B. L.; Prakobphol, A.; Burlingame, A. L.; Leffler, H.; Fisher, S. J. Structure and bacterial receptor activity of a human salivary proline-rich glycoprotein. J. Biol. Chem. 1991, 266, 17358-17368.

32. Dell, A.; Thomas-Oates, J. E. Fast atom bombardment-mass spectrometry (FAB-MS): Sample preparation and analytical strategies. In Analysis of Carbohydrates by GLC and MS; Biermann, C. J.; McGinnis, G. D., Eds.; CRC Press: Boca Raton, 1989; pp 217-235.

33. Garozzo, D.; Impallomeni, G.; Montaudo, G.; Spina, E. Structure of underivatized branched oligosaccharides by negativeion fast-atom bombardment mass spectrometry. Rapid Commun. Mass Spectrom. 1992, 6, 550-552.

34. Domon, B.; Müller, D. R.; Richter, W. J. High performance tandem mass spectrometry for sequence, branching and interglycosidic linkage analysis of peracetylated oligosaccharides. Biomed. Environ. Mass Spectrom. 1990, 19, 390-392.

35. Egge, H.; Peter-Katalinic, J. Fast atom bombardment mass spectrometry for structural elucidation of glycoconjugates. Mass Spectrom. Rev. 1987, 6, 331-393.

36. Laine, R. A.; Yoon, E.; Mahier, T. J.; Abbas, S.; de Lappe, B.; Jain, R.; Matta, K. Non-reducing terminal linkage position determination in intact and permethylated synthetic oligosaccharides having a penultimate amino sugar: Fast atom bombardment ionization, collision-induced dissociation and tandem mass spectrometry. Biol. Mass Spectrom. 1991, 20, 505-514. 